Illinois State University

ISU ReD: Research and eData

Theses and Dissertations

$9-6-2018$

\title{
Achieving Development In Destinations: Effects Of Tourism On Poverty, Inequality, And Quality Of Life
}

Jessica R. Linder

Illinois State University, jessica.linder93@gmail.com

Follow this and additional works at: https://ir.library.illinoisstate.edu/etd

Part of the Political Science Commons

\section{Recommended Citation}

Linder, Jessica R., "Achieving Development In Destinations: Effects Of Tourism On Poverty, Inequality, And Quality Of Life" (2018). Theses and Dissertations. 1017.

https://ir.library.illinoisstate.edu/etd/1017

This Thesis is brought to you for free and open access by ISU ReD: Research and eData. It has been accepted for inclusion in Theses and Dissertations by an authorized administrator of ISU ReD: Research and eData. For more information, please contact ISUReD@ilstu.edu. 


\section{ACHIEVING DEVELOPMENT IN DESTINATIONS: EFFECTS OF TOURISM ON \\ POVERTY, INEQUALITY, AND QUALITY OF LIFE}

\section{JESSICA R. LINDER}

\section{Pages}

For decades, political scientists and development practitioners have focused on poverty and inequality alleviation, as well as increased quality of life as key goals for the field of development. Research focused on key concepts such as social capital and tools like microfinance and trickledown tax structures for achieving these goals. Tourism, however, remained largely unstudied as a development tool, with most prior research focusing on sustainability and the economics of the industry. This study seeks to determine the effectiveness of tourism as a tool for development by examining its effects on poverty, inequality, and quality of life, as it becomes a larger or smaller part of the destination country's economy. This research sheds light on regions seeing the significant effect of tourism on development indicators.

KEYWORDS: development; tourism; poverty; inequality; quality of life; developing countries; Africa 


\title{
ACHIEVING DEVELOPMENT IN DESTINATIONS: EFFECTS OF TOURISM ON \\ POVERTY, INEQUALITY, AND QUALITY OF LIFE
}

\author{
JESSICA R. LINDER
}

A Thesis Submitted in Partial Fulfillment of the Requirements for the Degree of

MASTER OF SCIENCE

Department of Politics and Government

ILLINOIS STATE UNIVERSITY 
(C) 2018 Jessica R. Linder 


\title{
ACHIEVING DEVELOPMENT IN DESTINATIONS: EFFECTS OF TOURISM ON \\ POVERTY, INEQUALITY, AND QUALITY OF LIFE
}

\author{
JESSICA R. LINDER
}

COMMITTEE MEMBERS:

T.Y. Wang, Chair

Frank D. Beck

Noha Shawki 


\section{ACKNOWLEDGMENTS}

The pages that follow are years in the making and I would be remiss if I did not thank the institutions and people that made this research possible.

The first of these is most certainly the Stevenson Center at Illinois State University. I can't say enough about their unique program and enthusiastic, supportive staff. When life (and the Peace Corps) threw me curveballs, this staff was right there to help me find my path. I've been blessed in both my undergraduate degree at DePaul University and in my master's degree program to be surrounded by staff and faculty that truly and deeply care.

To the faculty of the Politics and Government Department, every one I have encountered has pushed me and taught me to think deeper and more critically. I have been challenged academically and taught to think in new ways that will serve me well for many years to come. Thank you for being great educators!

As my education career blended with my professional career, there were plenty of obstacles to overcome. Thank you to my Board of Directors at the Galesburg Area Chamber of Commerce who took a chance on a young Executive and granted me the flexibility to continue. Without your understanding of the importance of my education, I would not have been able to finish.

To Dr. Wang, Dr. Beck and Dr. Shawki, thank you for your patience, encouragement, flexibility, and for sharing your valuable time with me. I am so thankful for a thesis committee that was ready and willing to work with a non-traditional graduate student. Seeing where my thesis started to where it has come is truly incredible and a result of veteran educators. You knew exactly how to challenge me and prove to me that I had the ability to research and write at a level 
that I didn't know I had in me. Thank you for the time and energy you have volunteered and put in to this thesis!

My committee has also evolved over the course of my degree. The inspiration for this thesis has since retired, and continued to cheerlead from afar. Dr. Parodi, thank you for inspiring me, opening my eyes to areas of research where I found passion, and dragging me across the finish line. I consider our time and travels together, cherished memories. Salud!

Finally, a huge thank you to my family and support system. You've comforted a very sleep deprived and grumpy version of me that only few can say they've seen. I love you guys, and couldn't have done this without you.

J. R. L. 


\section{CONTENTS}

$\begin{array}{lll}\text { Page } & \end{array}$

ACKNOWLEDGMENTS

CONTENTS

TABLES

CHAPTER I: INTRODUCTION 1

$\begin{array}{ll}\text { Understanding Development } & 2\end{array}$

$\begin{array}{ll}\text { Tourism and Development } & 4\end{array}$

$\begin{array}{ll}\text { Purpose and Organization of Thesis } & 7\end{array}$

$\begin{array}{ll}\text { Limitations } & 9\end{array}$

CHAPTER II: REVIEW OF THE LITERATURE 10

$\begin{array}{ll}\text { Tourism and Poverty } & 10\end{array}$

$\begin{array}{ll}\text { Tourism and Inequality } & 13\end{array}$

$\begin{array}{ll}\text { Tourism and Quality of Life } & 17\end{array}$

$\begin{array}{ll}\text { Literature Review Conclusions } & 21\end{array}$

CHAPTER III: HYPOTHESIS AND METHODOLOGY 22

Dependent Variables $\quad 23$

$\begin{array}{ll}\text { Independent Variable } & 27\end{array}$

$\begin{array}{ll}\text { Control Variables } & 29\end{array}$

$\begin{array}{ll}\text { Potential Methodological Problems } & 32\end{array}$

CHAPTER IV: A QUANTITATIVE ANALYSIS OF TOURISM IN DEVELOPMENT 33

Descriptive Statistics 33

$\begin{array}{ll}\text { Correlation Analysis } & 35\end{array}$ 
$\begin{array}{ll}\text { Regression Analysis } & 36\end{array}$

$\begin{array}{ll}\text { Summary of the Findings } & 45\end{array}$

$\begin{array}{ll}\text { CHAPTER V: CONCLUSION } & 47\end{array}$

$\begin{array}{ll}\text { Main Findings } & 47\end{array}$

Limitations \& Recommendations for Future Research 49

$\begin{array}{ll}\text { Significance of the Study } & 52\end{array}$

$\begin{array}{ll}\text { REFERENCES } & 55\end{array}$

APPENDIX: SCATTERPLOTS OF TOURISM IN AFRICAN NATIONS 66 


\section{TABLES}

Table

Page

1. Frequencies in the Data Set

2. Descriptive Statistics for all Variables in the Data Set

3. Correlation Analysis for Dependent Variables and Tourism by Region

4. Regression of Poverty, Inequality and Quality of Life on Tourism and Other Explanatory Variables

5. Regression of Poverty, Inequality and Quality of Life on Tourism and Other Explanatory Variables in Africa

6. Regression of Poverty, Inequality and Quality of Life on Tourism and Other Explanatory Variables in Asia and Oceania

7. Regression of Poverty, Inequality and Quality of Life on Tourism and Other Explanatory Variables in Latin America 


\section{CHAPTER I: INTRODUCTION}

The global spotlight on development has been the focus of nongovernmental organizations and countries for many decades. The topics of extreme poverty, inequality, and quality of life are of special relevance in community and international development. Poverty reduction specifically has been a topic of discussion in the global spotlight for decades and has been looked at through many lenses. The United Nation's Post-2015 Sustainable Development Goals emphasize poverty reduction with the goal of eliminating extreme poverty by the year 2030. The goals also call for an extreme reduction in inequality and for a focus on health and well-being (“Sustainable Development Goals”).

Many development techniques exist and some have seen success in reducing poverty and inequality and boosting quality of life, including the widely researched and practiced efforts of microfinance. However, one understudied perspective for development has been tourism. Tourism has gained popularity around the world as a way of boosting a country's economy, and there are widely held beliefs in government and international development that tourism is an effective driver of development, both economic and human, for destination areas (Sharpley and Telfer 2015). There has been a significant amount of research on the economics of tourism, and more recently, its sustainability as an industry (Proenca and Soukiazis 2008). Little compelling academic research exists to provide support for the belief that tourism is affective for development though, and researchers continue to call for more study of its effects as results have been inconclusive or varied in prior studies. Advocates and agencies, nonetheless, continue to call for its use for achieving development goals both during the Millennium Development Goal era and now through the Sustainable Development Goals. The United Nations World Tourism Organization has even gone so far as to launch a platform for sharing research and best practices 
for making tourism a driver of the Sustainable Development Goals ("Tourism for SDG's"). This study aims to research the effectiveness of tourism as a tool for development and build on the body of literature, which will assist in making it more effective in the future.

\section{Understanding Development}

Development is the central focus of this thesis and encompasses the dependent variables in this study (poverty, inequality, and quality of life). However, development has been ambiguously defined in the literature, and the lack of an agreed upon definition has caused it to be highly contested. In "Theories, Strategies, and Ideologies of Development", Robert Potter (2014b) describes how changes in development practice have led to changes in the theoretical frameworks and definitions of development (83). Over several decades, the way development is practiced in the field has indeed changed drastically, mirroring and, Potter would argue, driving an industry-wide search for new theories and writing on development. The academic study of development and the emergence of the subject of development studies can be traced back to the 1960s (Potter 2014a, 16). In another work by Robert Potter, "The Nature of Development Studies" (2014a), he says that "development studies can make a strong claim to be crossdisciplinary in nature in that it serves to bring together a large number of fields in the study of poverty and inequality..." (16-17).

For the purposes of this study, development will refer to development ideologies as referred to by Hettne (1995). He defines development ideologies as the many goals and objectives that have "the intention to change society in some defined manner" (Potter 2014b, 85). These initiatives to affect change all "reflect some form of ideological base", which Potter says could include "social, economic, political, cultural, ethical, moral and even religious influences" 
(Potter 2014b, 85). This study seeks to analyze the development strategy of tourism and how it can create 'a defined change in society'. Such a defined change in society often references a metric of economic growth. However, some researchers feel that growth alone is too narrow of a scope for development. One of these researchers is A.P. Thirlwall (2014), who points out that economic growth is nothing more than the growth of per capita income, a measurement that has no way of acknowledging how income may be distributed amongst the population. He says that economic development "must imply a growth of living standards" and he goes on to say that "the well-being of people is a much more inclusive concept than the level of income alone" (Thirlwall 2014, 26). According to Desai and Potter (2014), development “... must be regarded as synonymous with enhancing human rights and welfare, so that self-esteem, self-respect and improving entitlements become central concerns of the development agenda", an idea they undoubtedly evolved from the writings of Denis Goulet (1971) and Amartya Sen (1983, 1999). Denis Goulet (1971) argues that development must include three components: life sustenance, self-esteem, and freedom (Thirlwall 2014, 26). The idea is that a country cannot be fully developed if it cannot provide basic needs to its citizens, if it is exploited by other nations or cannot "conduct economic relations on equal terms", or if its citizens cannot "determine their own destiny" (Thirlwall 2014, 26-27). Very similar to Goulet (1971), Amartya Sen $(1983,1999)$ argues that "development should focus on, and be judged by, the expansion of people's 'entitlements', and the 'capabilities' that these entitlements generate...” (Thirlwall 2014, 27). The 'entitlements' that Sen was referring to are goods or services that a person can legally and economically afford to acquire (Devereux 2001). He views capabilities as the freedom of choices that a person can make (Thirlwall 2014). In other words, Sen views development as being based more on economic opportunity than on moral rights. In reading these definitions of the 
components needed for true development beyond economic growth, it becomes clear that measures of poverty (both economic and multidimensional), inequality in a society, and quality of life or well-being are all critical pieces of development.

\section{Tourism and Development}

Tourism and development have a long history of interacting with one another. In the 1950s, practitioners began to use tourism in the creation of a development strategy influenced by the popular development theory of the time, modernization theory (Scheyvens 2015, 119). The tourism development literature continues to rely on modernization theory in the works of many researchers pointed out by Archer and Fletcher (1996), Fletcher (1989), Huse, Gustavsen, and Almedal (1998) and again by Alam and Paramati (2016). Modernization theory claims that development is a linear process where a country moves from a traditional to modern society driven by economic growth (Rostow 1960, Rostow 1967, Schmidt 1989). Modernization assumes that development is endogenous and focuses on factors internally within a county; it assumes that changing the internal factors will move the country towards modernization (Przeworski and Limongi 1997, 158). The perspective that economic development causes modernization is the idea that made tourism widely understood as a tool for development (Britton 1982a, Cater 1987, Harrison 1992, Mathieson and Wall 1982, Pi-Sunyer 1989), in part due to its ability to "transfer technology to increase employment, generate foreign exchange, increase gross domestic product, attract development capital, promote a modern way of life with Western values and generate rural transformations of traditional societies" (Telfer 2015, 41). There are two key components of modernization theory as it relates to tourism: driving the transition to mass consumption and contributions to regional economic development. 
According to Rostow's (1967) idea that a country follows along a path of stages as it develops, the final stage in the modernization process is "the age of high mass consumption" (Sharpley and Telfer 2015, 40). Following this line of thought, the development of mass tourism became the focus of development through the modernization lens. Sharpley (2003) studied socioeconomic development in Cyprus to find that mass tourism was a key contributor and referred to it as a growth pole in the country. The focus on mass tourism made modernization "the implicit base for many studies on tourism in developing countries" (Telfer 2015, 41). The second tie between modernization theory and tourism development is the focus on regional development. Telfer (2015) states that regional economic development strategies that focus on "transmission or diffusion of growth impulses" such as those that that focus on development poles for spreading investments in a region (Perroux 1955) are modernization strategies (42-43). The Mexican government used this approach in its tourism development plans by focusing development along tourist centers on the coasts of Mexico and using them as growth poles (Clancy 2001, Kemper 1979). This view of modernization theory and approach to tourism development represent the diffusion approach (Telfer 2015, 36)

The relationship between tourism and development is not always a positive one. In fact, some theories argue that tourism causes underdevelopment. In the 1970s and 1980s, social scientists began to question the dominant rhetoric of modernization theory using the newly popularized theory of dependency. Dependency theorists believe that relationships between countries have two types of players: the metropoles or centers and the satellites or periphery. The centers are developed nations that tend to be larger, more powerful, and more economically stable nations. Periphery countries, on the other hand, are underdeveloped nations who tend to be disadvantaged in some way. One hypothesis of dependency theory, according to Frank (1967), 
an early writer on dependency, is that as metropoles tend to develop, their satellites tend to become under-developed. The theory hypothesizes that the stronger the link between the center and the periphery, the greater the underdevelopment of the periphery country will be (Khan 1997, 990). This is because the center will be able to draw more goods and resources out of the periphery as the relationship becomes stronger. Dependency theory differed greatly from the preceding modernization theory in that it looked beyond internal factors and analyzed the historical relationships between nations.

Scholars subscribing to this more critical view of tourism are described as following what I have termed the Dependency Theory of Tourism. Britton was one of the earliest and most influential scholars in subscribing to this school of thought and writing a series of articles exploring the exploitation of Third World nations by the capitalist structures in control of the tourism industry. Britton (1982b) argued that these metropolitan enterprises are in control of the "nature and scope of tourism development in the former" (Sharpley and Telfer 2015, 292). In the same year, Jenkins (1982) wrote that tourism and tourists flow from developed nations into economically deprived, periphery nations with economic benefit to the developed countries being well-documented. The literature discusses three main manifestations of dependency in the field of tourism: the satellites being dependent on the metropole for foreign exports, foreign ownership of tourism companies creating dependence on the metropole, and the inability of the satellite to provide supplies furthering dependence on the metropole. This field of scholars criticized tourism for being "an industry dominated by large corporations which exploit the labor and resources of developing countries, cause environmental degradation, commodify traditional cultures, and lead to social disharmony" (Britton 1982ab; Scheyvens 2015, 119). Lea (1988) wrote similarly about three primary elements of international tourism: there are large companies 
acting as intermediaries who have control over the global tourism markets, it creates power imbalances between the First and Third World, and the Third World finds it very difficult to cut out these intermediary companies (5).

Modernization and dependency theory represent only two of many theories of development, and scholars are often divided on which theories they subscribe to. It is important to note that in development, no theory ever dies and they often build upon or respond to one another. Modernization theory contributed to the emergence of economic neoliberalism in the 1970s and 1980s as well as globalism following the turn of the century (Telfer 2015, 41). Some have argued that modernization has made a comeback in recent years. The hypothesis of this study is rooted in the modernization ideas that economic growth yields development, as we have seen in this literature.

\section{Purpose and Organization of Thesis}

The purpose of this study is to determine the impact of tourism on development using poverty, inequality, and quality of life - components of development - to evaluate the relationship. This goal of analyzing tourism as a tool for development will be accomplished by posing several questions: (1) Is tourism development an effective tool for poverty alleviation? (2) Is tourism development effective in reducing income inequality? (3) Is tourism development effective for improving quality of life? This thesis hypothesizes that tourism can be an effective tool for development by decreasing poverty, decreasing income inequality, and increasing quality of life in the destination country. The hypothesis in this study will be tested using quantitative analysis techniques. Using regression of data collected for 141 countries in the developing world, this study will analyze the effects of tourism on the dependent variables, 
represented by the poverty headcount ratio, inequality coefficients, and human development index scores. Shown in Chapter IV, results in developing regions support the hypothesis of this study and African countries as a region provide the strongest statistical support. Because of this, the region will be analyzed further to determine strategies being used and factors at play contributing to tourism development's success in Africa.

This study is laid out in five chapters. This first chapter served to introduce the topic of this study, tourism and development, and provide a brief background on it. Chapter two reviews the existing literature on topics of tourism and poverty, tourism and inequality, and tourism and quality of life. Chapter three presents the methods employed in the study. It identifies the variables, the corresponding measurements and statistical models. This chapter also discusses the data. Chapter four discusses the quantitative results and provides an analysis of the regressions performed to test the hypothesis. This chapter also explores possible factors contributing to the success of tourism for development in some regions. Finally, the conclusion chapter presents major findings and policy implications as well as the limitations of the study and recommendations for future research.

This thesis will work to expand the current understanding of how tourism operates in destinations and the effects that it has on residents in those destinations. Such an understanding will have important implications for future policies and practices related to tourism and development and may lead to new strategies for global goals of poverty eradication, inequality alleviation, and increased quality of life as outlined in the UN Sustainable Development Goals. 


\section{Limitations}

This study is limited in its ability to establish causation, which is frequently a challenge in research, especially tourism research. The findings are also limited by the available data. In the case of quantitative data, the results are only as good as the data collected by individual nations and The World Bank. It is also very difficult to collect data in remote countries and countries that are not transparent, causing a problem with quantity of data points. In any research, there are elements of researcher bias that limit the applicability of the study. All of these limitations have been taken into account. Efforts have been made to mitigate their effect in order to make the highest value contribution to the literature possible. 


\section{CHAPTER II: REVIEW OF THE LITERATURE}

This chapter presents a review of the research on tourism and poverty, tourism and inequality, and tourism and quality of life. Tourism and poverty has one of the broadest areas of existing literature in tourism. Past research in inequality provides starkly divided and opposite results. Different from poverty and inequality, tourism and quality of life is still an emergent research area. The following section will root each concept in the broader context of development and provide information on past research in the area as it relates to this study.

\section{Tourism and Poverty}

Since the late 1980 s, following the rise and fall of dependency theory, it has been widely accepted that tourism can have positive economic impacts on the economy and the residents in a destination. This impact "can be classified into seven major groups: income generation, employment generation, tax revenue generation, balance of payment effects, improvement of the economic structure of a region, encouragement of entrepreneurial activity, and economic disadvantage" (Vanhove 2005, 169).

In the 1990s, tourism's role in economic development began to emerge in the form of a poverty alleviation strategy called pro-poor tourism (Laws 2009, 144). The term was first used in the literature in 1999, even though the World Bank and United Nations Development Programme (UNDP) publicly supported the approach as early as 1990 quickly followed by the Organisation

for Economic Co-operation and Development (OECD) (Scheyvens 2015, 121). According to the Pro-Poor Tourism Partnership, pro-poor tourism put "poverty at the heart of the tourism agenda" (UK Department for International Development quoted in Nevin 2007, 52). Kakwani and Pernia (2000) more specifically defined pro-poor tourism as "tourism projects that 'enable the poor to 
actively participate in and significantly benefit from economic activity"' (Laws 2009, 143). Ashley, Roe, and Goodwin (2001) say that pro-poor "interventions aim to increase the net benefits for the poor from tourism, and ensure that tourism growth contributes to poverty reduction..." (xiii). They also say that there are three main strategies for using pro-poor tourism: "increasing access of poor to economic benefits, addressing the negative social and environmental impacts often associated with tourism" and overlapping the two by "focusing on policies, processes and partnerships" (Ashley and Roe 2002, 62). Pro-poor tourism stresses that it is an approach to tourism development rather than a sub-sector of it; "any kind of tourism can be made pro-poor" and it can be used and applied at any level in any destination or business (Scheyvens 2015, 125).

Pro-poor tourism can be administered both directly and indirectly. The Overseas Development Institute (ODI) says that pro-poor tourism should be applied on both the micro and macro level of development. ODI suggests doing this by including larger private sector tourism businesses in pro-poor tourism, in addition to focusing on small enterprises. The strategy consists of encouraging both large and small businesses to buy local products and hire local people and service providers (Nevin 2007, 52). Developers in this camp of pro-poor tourism want to keep pro-poor tourism from becoming a niche market by making it a mainstream business approach (Ashley and Ashton 2006, 3; Scheyvens 2015, 125). Pro-poor tourism can also happen indirectly when tourism causes gains in overall economic growth and they are "redistributed to the poor via progressive taxation and targeted government spending” (Laws 2009, 144).

Academics have been debating the effects of pro-poor tourism for multiple decades now. Jiang et al. (2011) found convincing evidence in their study that gross domestic product (GDP) per capita increases as tourism intensity increases (1183). They also found evidence that small 
island developing states who have higher intensity tourism industries also show less poverty on average. Ashley and Roe (2002) concluded that earnings for the poor go up in small but significant amounts due to pro-poor tourism, but more importantly they cited the finding that pro-poor tourism decreases vulnerability of citizens (68). Research seems to show that pro-poor tourism "can play a significant role in livelihood security and poverty reduction" at the local level (Ashley and Roe 2002, 78). Holden, Sonne, and Novelli (2011) studied locals in Elmina, Ghana and found that tourism has the high potential to reduce poverty, but that barriers to entrepreneurship and employment in the tourism sector are also barriers to poverty reduction. The World Bank and Overseas Development Institute, on the other hand, used a set of ten countries and calculated the amount of money from tourism that is estimated to go to each member of the population in a destination country based on the assumption that only $10 \%$ of tourism receipts will flow to locals. The study was a crude calculation, but concluded that benefits from tourism are "likely to be small" and remarked that it is surprising that "very few studies can answer the seemingly simple question which lies at the heart of the pro-poor tourism debate "What share of the financial benefits of tourism are enjoyed by poor people" (Mitchell and Ashley 2007, 21). Researchers argue though that the findings are far from conclusive due to small samples and inconsistent results.

While pro-poor tourism has garnered much attention and been widely used, there are still a fair amount of critics with solid ground to stand on. There has been little evidence on an economy-wide level suggesting nor proving that tourism reduces poverty; there are also few studies that have been able to quantify interactions between poverty and tourism in any significant way (Ashley and Roe 2002; Blake et al. 2008, 107). Furthermore, Blake et al. (2008) found that some of the tourism receipts in the developing countries utilizing tourism are being 
spent on imports or are paid in wages to foreigners all of which is money that is considered leakage and has no impact on poverty relief (108). Research on tourism and development indicators recurrently shows promising results, but needs more concrete data and conclusions behind them.

\section{Tourism and Inequality}

Inequality is a key part of the development discussion even though it has received significantly less fanfare than poverty until recently. De Janvry and Sadoulet (2016b) speak to the importance of focusing on equality by saying that "high inequality is generally thought to reduce economic growth in the long term, making greater equality potentially both intrinsic to wellbeing and instrumental to sustained growth" (248). Economic growth and rising GDP per capita in and of themselves are unlikely to reduce inequality alone. Policies should be created specifically with the intent of reducing income inequality in order to make a change (Azerrad and Hederman 2016; McElwee 2016). Tourism has been said to have an effect on inequality, although it is not agreed upon what the effect is.

Regional inequality is the most studied area of inequality as it relates to tourism. Proenca and Soukiazis (2008) have been prominent in writing about the inequality reducing effects of poverty. They found that international tourism is responsible for "reducing regional gaps among different locations in Spain, Italy, Greece, and Portugal”. Li, H. et al. (2016) also found that tourism can reduce regional inequality, because the surplus of tourism attractions pushes further development of the destination out of the core of the city to underdeveloped regions of the destination (84). Several groups of scholars studying the effects of tourism in China have had similar findings supporting that tourism can reduce inequality. Li, H. et al. (2016) found that 
domestic tourism specifically has the ability to reduce regional inequality in China, and $\mathrm{Li}$, Goh, Zhang Qiu, and Meng (2015) found that tourism has a more positive impact in China's developing regions. These findings led the researchers to conclude that growth caused by tourism might reduce regional inequalities. Opperman (1992) agrees that tourism can reduce regional inequality by saying that tourists that visit at least four different locations in Malaysia contributed to regional development. He also found that the tourists who were less active and visited only one location seemed to reinforce location-based inequalities. Other scholars say that tourism actually enlarges inequality in the destination. In discussing The Political Economy of Tourism in the Third World, Britton (1982b) claims the importance of studying how tourism, "while bringing undoubted benefits to many Third World countries, frequently also perpetuates class and regional inequalities, economic problems, and social tensions" (332). Two studies, one by Goymen (2000) and the other by Seckelmann (2002), focused on inequality in Turkey and found that areas that receive more tourism-related investment develop and grow much faster thus creating or enlarging regional inequality. Another subset of scholars argue that domestic tourism has a greater impact on inequality than international tourism, because there is more of it and it generates larger economic contributions (Massidda and Etzo 2012). In one of the first attempts at quantitative empirical analysis of domestic tourism and inequality, Haddad, Porsse, and Rabahy (2013) agree with this by finding that domestic tourism reduces regionally calculated inequality in Brazil. This study focuses on international tourism, so such results are unlikely to apply.

Despite the research on regional inequality, far less focus has been placed on the relationship between tourism and income inequality in the past, especially quantitative analysis of the subject. For the purposes of this study, income inequality is the area of most relevance in the discussion of inequality. Inequality is closely correlated with poverty, however most studies 
on the wealth generation of tourism do not address the distribution of that wealth. Some scholars believe that pro-poor tourism approaches can also be used to reduce income inequality citing its emphasis and ability to bring benefit to the most vulnerable groups in a country (Incera and Fernandez 2015). Along the same lines of thinking, a group of scholars researched and pointed to the potential of the tourism sector to bring employment to unskilled labor as a means of reducing inequality, seeing a clear relationship between the growth of the tourism industry and positive impacts on economic development (Durbarry 2004, Dritsakis 2004, Ivanov and Webster 2007, Kim et al. 2006, Eugenio-Martin et al. 2004).

There is an equally large body of research pointing to the inequality causing side effects of tourism, but few can identify a reason for it. Scheyvens and Momsen (2008) and Lee and O’Leary (2008) both found in separate studies that tourism actually contributes to income inequality. Lee (2009) found that states in the U.S. who were dependent on tourism have higher income inequality and have seen income inequality increase faster than the country as a whole. Despite the belief of Incera and Fernandez (2015) that pro-poor tourism can assist in alleviating inequality, their study found that high-income households in Galicia, Spain, saw a higher benefit from tourism than low income households supporting other findings that tourism creates inequality.

Another group of authors has come to a similar conclusion that tourism causes inequality, but they have also identified the high levels of leakage that are common to the industry to be the driving reason. Tourism is an industry with many transnational corporations and large scale players at the table, as referenced in the discussion of tourism and dependency theory. The control by transnational corporations often leads to foreign ownership and profits being sent back to the country where the company is headquartered. According to current statistics compiled by 
the UN Conference on Trade and Development (UNCTAD), "leakages in the tourism sector total up to $85 \%$ in some African least developed countries (LDCs), more than $80 \%$ in the Caribbean, 70\% in Thailand and 40\% in India" (Kinyondo and Pelizzo 2015, 67). Pleumarom (2007) made this view clear by saying that "residents do not get a fair share [of the revenue] because most of the tourism revenue is siphoned away by urban-based and foreign investors". Papatheodorou (2004) found that high levels of transnational corporations caused high barriers to entry for local providers and small businesses, which he found to have a negative impact on employment and income distribution. In Kinyondo and Pelizzo’s (2015) study, they quoted an interview with the Directeur des Affaires Communes of the Ministry of Tourism in Togo saying that "the tourism industry in Togo could trigger pro-poor growth under two conditions: an increase in the number of arrivals of international tourists and the development of a system of smaller, locally owned, hotels, for he believed that the profits generated by large, internationally owned hotels were repatriated and did not contribute in any meaningful way to the betterment of Togolese society" (67). In the end, their study found that growth as a result of tourism was stifled from reducing income inequality due to low wages, foreign ownership and vertical integration, which is when a company owns and controls their own supply chains.

It is difficult to find empirical evidence for the effect tourism has on inequality, and for some, the relationship between tourism and inequality is far less clear than for those referenced above. One study found that the relationship is entirely country-specific, citing examples of countries demonstrating strong arguments for the relationship being both positive and negative (Krakover 2004, 84). Others believe that the relationship is not necessarily country specific but state that most existing research has focused on individual countries making the results very difficult to apply on a broader scale (Alam and Paramati 2016, 115). Many of the results on 
tourism and inequality are less than encouraging, though some do still find possible positive outcomes. Alam and Paramati (2016) found in their study of tourism and inequality in 49 developing countries that tourism increases inequality. However, they also found that there is a threshold where tourism significantly reduces income inequality at double the current size of the tourism industry (124). Alam and Paramati (2016) offer the solution that governments must encourage small and medium sized tourism enterprises in their countries to give them a chance to compete with the transnational corporations. They believe that with greater local ownership and enterprises will come a decrease in inequality as it relates to tourism. Poverty and inequality are highly correlated with one another and the positive results of poverty reduction from tourism seem to indicate that there is something not being seen in research on tourism and inequality. It also seems to point out that there may be a better way to practice tourism to create similar results to that of poverty reduction.

\section{Tourism and Quality of Life}

Quality of life is an important concept in community and international development. One commonly held assumption is that tourism in a destination will cause economic development, and by extension, human development. Sen's $(1987,1993,1999)$ conclusion shifts the understanding of development and what is important for developed communities away from solely economic indicators to the bigger picture that we capture in "quality of life". Sharpley and Telfer (2015) said that the difference created was that elements of development (accelerating economic growth, reducing absolute poverty, and preventing negative impacts on development) "would be clustered around the central goal of enlarging human choices" (63). 
In the past, income has often been used as a proxy for measuring quality of life. Research later found that it was not an accurate measure. At very low levels of income, people do become happier due to sustained increases in their income, but people at moderate or high income levels only experience the same happiness for temporary amounts of time (Greenwood and Holt 2010, 35). This finding shows why income is not an accurate proxy for quality of life and supports Sen's $(1987,1993,1999)$ conclusions that quality of life goes beyond economics to include freedoms and decisions. Instead, researchers have shifted to using the Human Development Index (HDI) that was developed by Mahbub ul Haq and Amartya Sen in 1990 and continues to be published by the UNDP (Biagi et al. 2015). HDI captures the end result of development and "it argues that individuals must be the center of the development process and that they must be participants in the development of their choice" (UNDP 2013). While HDI is not an uncontested measure largely because it incorporates GDP, which is a measure of income, it is one of the most reliable measures of quality of life that exists (Biagi et al. 2015, 2).

The concept of well-being and quality of life in relation to tourism is the most sparsely researched of the three development indicators in this study. There is only a small group of researchers who have explicitly studied the relationship between tourism and quality of life. Jiang, DeLacy, Harrison and Mkiramweni (2011) studied small island developing states and found that higher standards of living, higher HDI, and lower infant mortality are all found in states with higher tourism intensity. Biagi et al. (2015) used panel data to find that tourism had a significant positive impact on literacy rates and came to the conclusion that investing in tourism may have a positive effect on human development. Pro-poor tourism has itself incorporated a human development lens into its utilization strategies by creating livelihood benefits for the poor which include things like potable water and access to markets through roads (Sharpley and Telfer 
2015, 66). Volunteer tourism, called voluntourism, is another reflection of the shift in development to emphasizing quality of life in the destination by giving tourism a "humanitarian purpose'. Voluntourists are people who volunteer to "undertake organized holidays that might involve aiding or alleviating the material poverty of some groups in society, the restoration of certain environments or research into aspects of society or environment" (Wearing 2001, 1).

A significant amount of the research on quality of life that has been done is on the relationship between the host and the tourist (Deery, Jago, and Fredline 2012; Ivlevs 2016; Moufakkir and Reisinger 2012; Nunkoo and Gursoy 2012; Reisinger 2015; Sharpley 2014; Woo et al. 2015). Much of tourism research relating to quality of life applies social exchange theory, examining interactions between the tourist and the host with the lens that both parties seek benefits from an exchange relationship (Ap 1990, 669; Ward and Berno 2011). Several studies have found that hosts recognize the economic impact of tourists and also think other impacts are important (Andereck et al. 2007; Biagi et al. 2015). Figini et al. (2009), in their study of seaside destinations in Italy, is one of these studies and concluded that residents perceive tourists as having a positive impact on improving their life conditions beyond simply economic. Additionally, Marrocu and Paci (2011) used econometric techniques to analyze European countries and concluded that "tourism can be a channel for transmitting new ideas and knowledge for local firms and regions".

Biagi et al. (2015) found that in general, tourism and human development are correlated, but in some examples, that is not the case. The fact that both small and developed nations experience underdevelopment tells us that above a certain threshold for tourism, negative consequences for quality of life are expressed and exhibited in changes in HDI (5). Greenwood and Holt (2010) captured the sentiment by saying that "when economic growth has negative 
impacts on quality of life, this offsets the benefits of income growth" (33). Some research has found that tourism decreases quality of life for several reasons. Biagi et al. (2012) found that tourism increases the cost of living by driving prices up with second homes, etc. and decreases quality of life for locals. Some studies reference an increase in crime brought about by tourism as a reason for a decrease in quality of life (Schubert 2010; Biagi and Detotto 2014). Others cite a concern for the degradation of local environments and socio-cultural life as the reason for a decrease in quality of life (Andereck et al. 2007; Lindberg et al. 2001), sometimes despite recognition by local residents of the economic benefit to them (Andereck et al. 2007).

Other studies have found that there are certainly factors impacting the results on relationships between tourism and quality of life. In a study of tourism in Orange County, Indiana, U.S., Yu et al. (2011) found that when tourism development is in its initial stages, the anticipation residents have of the effects from tourism causes them to have a higher tolerance for social costs and perceive tourism as having no effect on quality of life. This is one of very few findings linking the stage of tourism development to the perception of tourism and quality of life. Andereck and Nyaupane (2011) found another factor is the amount or frequency that residents interact with tourists impacts their positive perceptions of tourism.

The majority of studies on quality of life are about a specific place at a specific point in time and are largely qualitative. This makes the findings extremely difficult to apply on a broader scale, despite the fact that most studies have found the economic impact of tourism is perceived as positive by residents (Biagi et al. 2015). This study will focus in on objective measures of quality of life instead of on resident's perceptions of tourism. 


\section{Literature Review Conclusions}

The above review shows that findings on the relationship between development and tourism are mixed. Poverty is the most researched of the development indicators in relation to tourism; there is an entire body of research on pro-poor strategies. Conclusive research on the effect of tourism on poverty reduction is small, however. The effect of tourism on inequality is the most disagreed upon indicator of development in this study. It also has the most proponents of the indicators saying that the relationship between it and tourism may be negative for society. Very little quantitative research exists on the relationship between tourism and HDI, in part because it is newer on the development scene and more difficult to isolate than the purely economic indicators. Studies have struggled to provide conclusive results to support what seems to be the practitioners' belief that tourism can have a positive effect on development. Due to these inconclusive and/or contradictory findings in the existing literature, further analysis of the relationship between tourism and the three aspects of development is needed. 


\section{CHAPTER III: HYPOTHESIS AND METHODOLOGY}

This study seeks to answer the following research questions using quantitative analysis:

1) Is tourism development an effective tool for poverty alleviation?

2) Is tourism development effective tool in reducing income inequality?

3) Is tourism development effective for improving quality of life?

These research questions all work to address the broader topic of tourism and development, and each question addresses a different metric of development. This study will test how tourism impacts development in destination countries while controlling for variables that have been shown to impact the dependent variables. The study will be conducted in SPSS software using correlation analysis and ordinary least squares (OLS) regression analysis. Secondary data obtained from the World Bank Open Data database ${ }^{1}$ and United Nations ${ }^{2}$ for 141 countries in developing regions will be used in the analysis. The countries represented in the sample are spread throughout developing regions of the world and represent nations of various sizes, populations, and economy sizes.

There are three dependent variables in this study that will be used to assess and measure development. The dependent variables are poverty, inequality (GINI), and quality of life (HDI). The independent variable in this study is tourism development. The control variables that will be used are labor force participation (LFP), education expenditures, foreign aid, government spending on welfare (Health), and population density. To further analyze the data, the countries have been categorized according to their geographical location in Africa, Asia, Latin America

\footnotetext{
${ }^{1}$ Data collected from The World Bank Open Data (https://data.worldbank.org/indicator, access August 3, 2018).

${ }^{2}$ Data collected from UN Data (http://data.un.org/, access August 3, 2018).
} 
and Oceania. Region will be used as a control variable as well to catch any unrepresented control variables; this is due to the similarities in culture of regions. The regression equation formed by the variables in this study is as follows:

Poverty / GINI / HDI = f(Tourism, LFP, Education, Foreign Aid, Health, Population, Region)

The variables in this study are all represented as averages of five year periods. Averages were taken to mitigate the effects of large swings in the data for single years. The calculation of average values for the variables in this study also decreases the number of cases that will be eliminated due to missing data in singular years. Time is incorporated into the study by lagging the variables to ensure that causal direction is properly demonstrated. Data of the key independent variable and all of the control variables are measured from 2005 to 2009 . The dependent variables are measured from 2010 to 2014.

As you will see in Chapter IV when the data for tourism development is studied by region, Africa as a region has a particularly strong statistical result that supports the hypothesis of this study, making it a particularly interesting region to study. Literature will be examined to identify strategies being used and strengths of the industry in Africa that are causing tourism to have a stronger positive effect on development indicators than other areas of the developing world.

\section{Dependent Variables}

As indicated, there are three dependent variables: poverty, inequality and quality of life. Poverty is a human rights concern that is more complex than simply lack of income (Elliot 2014, 31). Poverty is often thought of as a shortage or lack of income, because that is how the word is 
used colloquially. Researchers however, stress that poverty is a multidimensional concept, which can include deprivation of "both physical and mental health, education, social life, environmental quality, spiritual and political freedom, and general well-being ('happiness')" in addition to deprivation of income (White 2014, 60). The Human Poverty Index (HPI) is a measure that was created by the UNDP and has been in circulation since 1997. HPI takes a multidimensional approach to measuring poverty and measures the "percentage of populations not expected to live until the age of 40, illiteracy rates, the percentage of people lacking access to health services and safe water, and the percentage of children under five years who are moderately or severely underweight" (Elliot 2014, 31). Some researchers do argue though that income poverty is the most important perspective to view poverty from, because there is a high correlation between income and other measures of well-being such as health and education status" (White 2014, 60). The most common measures of poverty subscribe to the income driven view of poverty. One of the most common measures is the percent of people falling below the poverty line (White 2014, 61). It is important to note the different views and implications of the views of poverty in development. Viewing poverty in terms of income will often lead to a strategy of economic growth, whereas a multidimensional view of poverty will lead to an emphasis on changing social policy. This study will examine poverty from an income perspective, since other measures of well-being are being taken into account alongside of poverty. For test one, poverty will be operationalized as the poverty headcount ratio of the country from 2010 to 2014 . This ratio is the percentage of the population who lives below $\$ 1.90$ per day at 2011 levels of purchasing power parity (PPP). PPP rates will be used in order to make the poverty line comparable despite variances in price and exchange rates across time and space, and it takes into account differences in purchasing power in a way that market exchange rates cannot. White (2014) was a proponent 
of using PPP rates for studying poverty headcount ratios to create comparability of poverty lines that does not exist otherwise. This measure utilizes the international poverty standard of $\$ 1.90$ per day in income instead of the poverty headcount ratio measured at national poverty lines. The two measures are highly correlated, so there is likely little to no difference in result. The international poverty measure however is a stronger measure because it is standardized across time, due to the use of purchasing power parity, and across currency.

Income inequality refers to the relative difference between the richest and the poorest percentages of a country, and the general public often discusses it in a negative political context. On its own, income inequality does not tell the full story of a country's economic reality. It is only a term that may tell of a larger problem, because talking about inequality "without a sustained discussion of its effects and causes tells us very little" (Azerrad and Hederman 2016, 168). Unlike absolute poverty which requires knowledge of and reference to a relative line between impoverished citizens and those with some level of liquidity, inequality "is an absolute concept that does not require definition of a threshold" (De Janvry and Sadoulet 2016b, 248). However, for the sake of research and comparison, a value was needed that could be easily compared across nations. The Gini coefficient is commonly used for this purpose and is a measure of income inequality that ranges from 0 to 1 , with one denoting perfect inequality (one person earns all the income) and zero denoting perfect equality (each person earns equal income) (De Janvry and Sadoulet 2016a). Test two, which will analyze the relationship between tourism and income inequality, will use an average of Gini index values from 2010 to 2014 for the dependent variable. The Gini index is calculated by the World Bank and is based on the Gini coefficient. The Gini index is a calculation of the percentage of total income received against the cumulative number of recipients calculated using a Lorenz curve, which is way to graph the 
distribution of wealth in a society. The Lorenz curve is then used to measure the area between the point on the curve and the point at which absolute equality would theoretically be present. The number is then "expressed as percentage of the maximum area under the line"3. Numbers closest to 0 percent represent perfect or near perfect equality and numbers closest to 100 represent perfect or near perfect inequality.

Quality of life is the final dependent variable in this study. According to ecological economist Robert Costanza et al. (2008), "while quality of life (QOL) has long been an explicit or implicit policy goal, adequate definition and measurements have been elusive...". Some scholars have put clear definitions to the concept though. According to Greenwood and Holt (2010), the term 'quality of life' refers to non-market goods that impact the standard of living in a community such as good health, education, culture, parks, and safe neighborhoods. It is important to note that quality of life is a contributor to standard of living, but is not synonymous; standard of living is a financial metric while quality of life encompasses much more. Well-being is a commonly used synonym of quality of life and was the focus of Amartya Sen. Sen (1987, 1993, 1999) is famous for his conclusion that income and consumption, traditional beliefs of what was needed for well-being, were only part of the story. He found that "the most crucial factor [in well-being] is capability of individuals to achieve conditions in life" (Biagi et al. 2015, 1). Quality of life is a difficult concept to quantify, since it cannot be measured in financial terms. Two of the most common measurements are the Human Development Index (HDI) published by the United Nations Development Programme and the World Happiness Report

\footnotetext{
${ }^{3}$ World Bank, The. Gini Index (World Bank Estimate) [Data file and code book]. Retrieved from https://data.worldbank.org/indicator/SI.POV.GINI.
} 
rankings ${ }^{4}$, which is also published by the United Nations. The third test of this study will analyze the relationship between tourism and quality of life and will use HDI as the metric. HDI is a composite statistic that combines life expectancy, education, and income for measuring standard of living. HDI numbers range from 0 to 1 with 0 being the least developed and 1 being the most developed nations. The test will use an average of HDI values from the 2010 to 2014 as the dependent variable.

\section{Independent Variable}

The independent variable being tested in this study is tourism. Tourism is a word used often in everyday speech and study; however, much like development, it is a term that can be difficult to define and has no single, widely used definition (Sharpley and Telfer 2015). In fact, many definitions for tourism and "tourism-related phenomena" directly challenge or contradict one another, making choosing one difficult (Smith 1995, 39). The World Tourism Organization (WTO) has put vast amounts of effort into standardizing international definitions related to the 'tourist', making distinctions based on the length a person is traveling for (Smith 1995, 21). Two types of definitions exist in the literature: factual definitions and theoretical definitions. Jafari (1977) strongly urged that a definition bridging the two categories be used to study tourism and came up with the following. It will be the accepted definition in this study, because it most closely represents the available data on tourism:

"The study of man away from his usual habitat, of the industry which responds to his needs, and of the impacts that both he and the industry have on the host's socio-cultural, economic, and physical environment." (quoted in Sharpley and Telfer 2015, 16)

\footnotetext{
${ }^{4}$ Helliwell, J., R. Layard , \& J. Sachs. 2018. World Happiness Report 2018, New York: Sustainable Development Solutions Network. Retrieved from http://worldhappiness.report/.
} 
This definition could be considered problematic, because it only addresses one criteria of being a tourist. The criteria that the above definition does refer to is a change in the 'usual habitat' or usual environment of a person. The WTO suggests that places frequently visited by a person or places close to their residence be considered part of their usual environment. For travel to be considered tourism, the person must leave this environment (Smith 1995, 25). Length of stay is another criterion of being a tourist and is one of the most contested aspects. To be a tourist a person must stay overnight in the destination; use of the word overnight has created much debate for which scenarios should count but will not be debated in this thesis. To be counted as a tourist the person must stay overnight and cannot stay for more than one year. The person also must not have intent to move to the destination (Smith 1995, 26). The third criterion for being a tourist is that the person must not be traveling to the destination in search of "remuneration - wages, salaries, payments-in-kind (but excluding travel allowances or small participation fees)" (Smith 1995, 27). This would classify the person as a migrant, even if temporary, and not a tourist. Some definitions and lots of research make further distinctions to the definition of tourist by classifying between types of travelers and the purpose of their trips.

In this study, the numerical representation of tourism measures tourism's share of the economy $^{5}$ and is represented as tourism as a percent of GDP. The measure is for the years 2005 to 2009 and utilizes data from The World Bank. This was chosen to represent tourism for a couple of reasons. First, unlike tourism arrivals, tourism in relation to the economy, which uses tourism expenditure, captures the economic inflow attributable to tourism. Incorporating the component of economic inflow is important particularly when discussing tourism in relation to

\footnotetext{
${ }^{5}$ World Bank, The. International Tourism, Receipts (Current US\$) [Data file and code book]. Retrieved from https://data.worldbank.org/indicator/ST.INT.RCPT.CD.
} 
poverty or income inequality as they are also economic measures. Since tourism is "officially recognized as a directly measurable activity", tourism no longer has to rely on indirect measures such as balance of payment statistics to calculate tourism's economic impact. Secondly, the variable is expressed in relation to GDP to standardize the numbers across all of the countries ${ }^{6}$. Without standardizing the data, it may look as though more developed and larger nations would have exponentially larger economic inflows from tourism and small or underdeveloped countries would have very small numbers when in relation to income alone. In reality, the small nation may be bringing in a higher percentage of revenue from tourism than the larger nation. Raw numbers tell us very little about the sector compared to others. Without standardizing measures, the results would be much less trustworthy.

\section{Control Variables}

In order to accurately measure the relationships of tourism with each of the three dependent variables, control variables need to be used to mitigate the effects of other variables that could affect the dependent variables. Each of the test models will control for labor force participation, government spending on education, foreign aid, government spending on welfare, and population density. The chosen control variables are based on variables tested in the current literature for the dependent variables. All of the control variables in this study are averages for the years 2005 to 2009 .

\footnotetext{
${ }^{6}$ Tourism receipts were also analyzed providing a whole dollar amount to compare the percentage measurement used. No variance in the results between the two indicators was found, giving no reason to switch from using tourism as a percent of GDP to a raw number in this study.
} 
Involvement in the labor force is measured using a World Bank data set called labor force participation rate, which is measured as the percentage of the population, ages 15-64, who are working in the labor force ${ }^{7}$. Labor force participation is being controlled for because of the belief in pro-poor tourism research that developing tourism creates local jobs which benefit the poor. Increased labor participation in all industries could also be a factor in decreasing poverty. In order to measure just the result of tourism and not indirect results, labor force participation must be controlled for.

Education ${ }^{8}$ in this study is measured as a government's expenditure on education in US dollars represented as a percent of total government expenditure. Education plays a role in lifting people out of poverty, reducing inequality, and has a key role in human development; therefore, it must be held constant. This measurement of education standardizes the values by taking them as a percent of total government expenditures ${ }^{9}$.

Foreign aid ${ }^{10}$ is a measure collected by the Organisation for Economic Co-operation and Development (OECD) and provided to The World Bank. Foreign aid is a measure of official development assistance money received. It is measured in US dollars and represented as a

\footnotetext{
${ }^{7}$ World Bank, The. Labor Force Participation Rate, Total (\% of Population Ages 15-64) (Modeled ILO Estimate) [Data file and code book]. Retrieved from https://data.worldbank.org/indicator/SL.TLF.ACTI.ZS.

${ }^{8}$ World Bank, The. Government Expenditure on Education, Total (\% of Government Expenditure [Data file and code book]. Retrieved from https://data.worldbank.org/indicator/SE.XPD.TOTL.GB.ZS.

${ }^{9}$ Literacy rates were not used in this study due to the extremely limited amount of data points for this measure. Government's expenditure on education also provided an economic measure of education for more clear comparison with the other economic measures in this study.

${ }^{10}$ World Bank, The. Net Official Development Assistance Received (Current USD) [Data file and code book]. Retrieved from https://data.worldbank.org/indicator/DT.ODA.ODAT.CD.
} 
percent of the country's GDP to normalize the variable. The measure specifically measures assistance money flowing to developing countries and the information is reported by donor countries. Aid is being controlled for because it is an outside economic force that could affect poverty, inequality, and quality of life, but is completely unrelated to tourism which this study seeks to isolate.

Spending on welfare ${ }^{11}$ is measured using health expenditures per nation from The World Bank. The OECD has an indicator called social expenditure data that focuses on measuring spending on old age, survivors, incapacity-related benefits, health, family, active labor market programs, unemployment, housing, and other social policy areas. However, the data only exists for 35 countries belonging to the OECD, which is not nearly a large enough scope for this study. Instead health expenditures will be used as a proxy for welfare spending. The number represents the total spent by both public and private entities and is normalized as a percent of GDP for the years 2005-2009. Welfare, similar to foreign aid, is an outside economic force that could affect poverty, inequality, and quality of life, so it must be controlled for.

Finally, population density ${ }^{12}$ is a World Bank metric that measures population per square kilometer for each country. Population is always an important variable to control for in development research, because the number of people in a given area could determine what services are available to the population. It may also determine what kind and the amount of opportunities and freedoms that a person has access to as Sen $(1983,1999)$ emphasized. Access to services and freedoms could impact all of the dependent variables in this study.

\footnotetext{
${ }^{11}$ World Bank, The. Current Health Expenditure (\$ of GDP) [Data file and code book]. Retrieved from https://data.worldbank.org/indicator/SH.XPD.CHEX.GD.ZS.

${ }^{12}$ World Bank, The. Population Density (People per Sq. Km of Land Area) [Data file and code book]. Retrieved from https://data.worldbank.org/indicator/EN.POP.DNST.
} 


\section{Potential Methodological Problems}

Establishing causality in a study of this nature can be extremely difficult. Many authors in the field of tourism studies have called for more causal research to strengthen arguments and the field as a whole. To minimize the causality issue, data of independent variables are lagged, i.e., data of the key independent variable and all of the control variables are measured from 2005 to 2009. The dependent variables are measured from 2010 to 2014 . The rationale is that none of the independent variables would show an instant effect on the dependent variables. Lagging the variables allows time for the effect of the independent variable to take place before the dependent is measured.

Poor data collection by nations is also a limiting factor and could potentially change the outcomes. Many developing countries do not have the infrastructure or the labor force to collect accurate data. Some do not have the ability to collect data at all, which causes for drastically smaller data sets than researchers desire. Another limitation is that both qualitative and quantitative studies are always subject to the author's subjective bias. Reviewing past literature and focusing on the variables can help to mitigate this issue. 


\section{CHAPTER IV: A QUANTITATIVE ANALYSIS OF TOURISM IN DEVELOPMENT}

Quantitative analysis in this chapter reveals that the effects of tourism are dependent on the region of the nation. In regions that are generally characterized as developing regions of the world, tourism has a positive impact on development. This chapter provides in depth analyses of the data in this study and results leading to this conclusion.

\section{Descriptive Statistics}

Descriptive statistics provide context to the data and can sometimes provide glimpses into the results. The sample of cases in this study is diverse - representing various regions of the developing world. As Table 1 shows, of the 141 cases, or countries, the data set covers all the major regions of the developing world, and each region represents around a third of the data set. To simplify the analysis, some regions have been grouped with other like regions in order to raise the sample sizes of the correlations and regressions. Specifically, Asia and Oceania have been grouped together since they are geographically similar and share the culture of the East. Latin America is not grouped with any other region, however, it does include Caribbean nations in the region.

Table 1: Frequencies in the Data Set

\begin{tabular}{|c|c|c|}
\hline \multicolumn{3}{|c|}{ Frequency by Region of the World } \\
\hline Country & $\mathbf{N}$ & $\%$ \\
\hline Africa & 49 & 34.8 \\
\hline Asia \& Oceania & 59 & 41.8 \\
\hline Latin America & 33 & 23.4 \\
\hline Total & 141 & 100.0 \\
\hline
\end{tabular}


It is important to understand the values of data included in the data set. Table 2 provides the mean values of the key independent and dependent variables in the study. The mean value of poverty for the 141 countries is $19.27 \%$ of the population of a country living on less than $\$ 1.90$ a day at 2011 international prices. Poverty values have the highest range between the regions of any variable. Africa has the highest poverty headcount ratio percent, and Latin America has the lowest ratio percent with a difference of 32.93 between the regions. The mean Gini index score is 40.55 on a scale of $0-100$ with 0 representing perfect or near perfect inequality. Africa has the highest economic inequality with an average Gini index of 41.66 and is $2.7 \%$ higher than the average for the data set. The mean Human Development Index value is 0.69 on a scale of $0-1$ with 0 being the least developed nations and 1 being the most developed nations. Africa has the lowest average of any region for HDI values; it sits 28\% lower than highest region's HDI average and $20 \%$ lower than the average for the data set. Tourism has a mean value of $6.44 \%$ of GDP. Latin America has the highest average values for tourism compared to other areas of the world; this is likely due to small island states included in the region that are heavily reliant on tourism.

Table 2: Descriptive Statistics for all Variables in the Data Set

\begin{tabular}{|l|rr|r|r|r|}
\hline \multicolumn{7}{|c|}{ Means for All Variables } \\
\hline Country & Poverty & Gini & HDI & \multicolumn{1}{l|}{ Tourism } \\
\hline Africa & 38.47 & 41.66 & 0.52 & 4.52 \\
\hline Asia \& Oceania & 7.35 & 35.68 & 0.71 & 6.85 \\
\hline Latin America & 5.54 & 47.77 & 0.72 & 8.56 \\
\hline Total & 19.27 & 40.55 & 0.65 & 6.44 \\
\hline
\end{tabular}


Descriptively, the mean values of the variables by region seem to provide support for the hypothesis. Africa, for example, has the lowest average value for tourism as a percent of GDP and the highest average values for poverty and inequality. It also has the lowest average value for quality of life. This means that in the case of Africa, negative correlations between tourism and poverty and Gini, and a positive correlation between tourism and HDI are possible and should be checked for. Such correlations would be statistical evidence in support of the hypothesis.

\section{Correlation Analysis}

Correlation analysis is a much stronger statistical tool than those used for evaluating the descriptive statistics; regression is more powerful than correlations and will be utilized later in the chapter. Correlation analysis measures the strength of the bivariate relationship between two variables measured at interval level. In this section, bivariate relationships between tourism and each of the dependent variables that are serving as indicators of development will be evaluated. Each of the tables in this section displays correlation coefficients; they describe the strength of the relationship, the signs describe the direction of the relationship and the coefficients are marked with their statistical significance or how trustworthy the result is.

Initial analysis of correlation results can be found in Table 3 broken down by region of the developing world. The results show that only a couple of correlations in Africa are statistically significant, and support the hypothesis. For African countries, the correlation coefficient between tourism and poverty is statistically significant and bears a negative sign but between tourism and HDI, the relationship is statistically significant and bears a positive sign. More simply, in Africa, an increase in tourism is associated with a decrease in poverty and with an increase in quality of life. The relationship between tourism and Gini is statistically 
insignificant for African countries. Meanwhile, all correlation coefficients are statistically insignificant for countries in Asia and Oceania and Latin America. Lack of statistically significant results in these regions means there is no relationship demonstrated in this analysis. The findings in Africa, however, support the hypothesis by showing that tourism can reduce poverty and increase quality of life.

Table 3: Correlation Analysis for Dependent Variables and Tourism by Region

\begin{tabular}{|l|r|r|r|}
\hline \multicolumn{3}{|c|}{ Correlations between Dependent Variables and Tourism } \\
\hline $\begin{array}{c}\text { Dependent } \\
\text { Variable }\end{array}$ & \multicolumn{1}{|c|}{ Africa } & Asia \& Oceania & Latin America \\
\hline Poverty & $-0.473 * *$ & -0.128 & 0.033 \\
\hline Gini & -0.033 & -0.010 & -0.042 \\
\hline HDI & $0.461 * *$ & 0.011 & 0.237 \\
\hline N & $34 / 32 / 49$ & $34 / 34 / 58$ & $18 / 18 / 33$ \\
\hline
\end{tabular}

$* \mathrm{P}<0.05, * * \mathrm{P}, 0.01, * * * \mathrm{P}<0.001$

To assure that the bivariate relationships seen in the correlation analysis are not spurious, a multivariate analysis is in order.

\section{Regression Analysis}

Regression analysis goes a step beyond correlation analysis and predicts the relationship between variables while holding other variables constant. Because all of the dependent variables are measured at interval levels, ordinary least squares (OLS) regression is used to estimate the effects of the variables on one another. The multivariate regressions hold other predictive 
variables constant, allowing researchers to clearly delineate the relationship between two variables. With poverty, Gini coefficients and HDI as the dependent variables, the regression analysis includes tourism as the key independent variable and five control variables (labor force participation, education, foreign aid, welfare, and population), as well as regional variables. Two regional variables, Africa and Latin America are included in the analysis with Asia and Oceania as the base category. Results of the regression are displayed in Table 4 below. Controlling by region strengthens the statistical models and serves as an added control variable.

1314 Table 4: Regression of Poverty, Inequality and Quality of Life on Tourism and Other Explanatory Variables

\begin{tabular}{|l|l|l|l|}
\hline Independent Variables & \multicolumn{1}{|c|}{ Poverty } & \multicolumn{1}{c|}{ Gini } & \multicolumn{1}{c|}{ HDI } \\
\hline \multirow{2}{*}{ Tourism } & $-.611^{*}$ & .033 & .001 \\
& $(.284)$ & $(.154)$ & $(.001)$ \\
\hline Labor Force & $.663 * * *$ & .108 & $-.002^{* * *}$ \\
Participation & $(.133)$ & $(.074)$ & $(.001)$ \\
\hline \multirow{2}{*}{ Education } & -.217 & .030 & -.002 \\
& $(.324)$ & $(.177)$ & $(.002)$ \\
\hline \multirow{2}{*}{ Foreign Aid } & $.473 * *$ & $-.202^{*}$ & $-.004 * * *$ \\
& $(.148)$ & $(.096)$ & $(.001)$ \\
\hline \multirow{2}{*}{ Welfare } & .151 & .839 & .001 \\
& $(.870)$ & $(.535)$ & $(.005)$ \\
\hline \multirow{2}{*}{ Population Density } & -.001 & -.002 & $2.387^{-5} * *$ \\
& $(.005)$ & $(.002)$ & $(.000)$ \\
\hline \multirow{2}{*}{ Africa } & $20.258^{* * *}$ & $5.146^{* *}$ & $-.119^{* * *}$ \\
& $(3.656)$ & $(1.970)$ & $(.020)$ \\
\hline \multirow{2}{*}{ Latin America } & -6.898 & $10.471 * * *$ & $.051^{*}$ \\
& $(4.674)$ & $(2.490)$ & $(.024)$ \\
\hline Adjusted $\mathbf{R}^{2}$ & .695 & .360 & .654 \\
\hline Number of Cases & 67 & 65 & 95 \\
\hline
\end{tabular}

Note: Standard errors are in parentheses.

$* \mathrm{P}<0.05, * * \mathrm{P}, 0.01, * * * \mathrm{P}<0.001$

${ }^{13}$ Variance inflation factors were run to test for multicollinearity. All of the scores were between one and two, showing no issue of multicollinearity.

${ }^{14}$ Heteroskedasticity was tested using normal probability plots of residuals; there were no issues. 
The most important results in the regression shown in Table 4 are that of tourism, since it is the key independent variable testing the hypothesis. Tourism is only found to have a statistically significant effect on poverty and it is significant at 0.05 level. The data shows that increases in tourism led to a reduction of poverty. A similar statistical result was observed in a study of tourism in Tanzania that found that the poor captured between $18 \%$ and $28 \%$ of incountry spending by tourists, a number the authors noted is significantly higher than average (Mitchell, et. al 2009). This result supports the hypothesis of the study and can be explained with support from the literature that tourism can be made pro-poor.

Analysis of the results in Table 4 disclose that labor force participation has a statistically significant effect on poverty and on HDI. These results are somewhat puzzling, because they show that increases in labor force participation cause an increase in poverty and a reduction in quality of life. One would expect that increases in labor force participation would cause decreases in poverty due to the increased number of people receiving wages. Further analysis into this result shows that the correlation coefficients for labor force and poverty and labor force and HDI are far higher in Africa than in all other regions of the world. One explanation for this can be found in Kinyondo and Pelizzo's (2015) writing that the jobs created by tourism are low wage jobs that contribute to the emergence of the working poor.

Foreign aid was found to have a statistically significant effect on poverty, inequality, and quality of life. The regression results in Table 4 show that as foreign aid increases, it causes poverty to increase, inequality to decrease, and quality of life to decrease. According to Asongu and Nwachukwu (2017), there is a wealth of recent literature challenging the effectiveness of aid with arguments from the neocolonial nature of foreign aid to lack of recipient nation's control 
over how aid dollars are used (283). These results would support this group of scholars and would add to the body of literature which questions foreign aid's role in sustainable development.

Population density was also shown to have a statistically significant effect on the development indicator of HDI. While it's effect is significant, the regression coefficient is very small meaning that increases in population density cause very small but significant increases in quality of life.

The results in Table 4 show that Africa has statistically significant and higher poverty and inequality and lower HDI than Asia and Oceania, the base category. Latin America has statistically significant and higher inequality and HDI than Asia and Oceania. Simply put, Africa has a higher poverty rate and lower quality of life than the east. Both Africa and Latin America have higher inequality than the eastern world. The strong and statistically significant results for Africa and for Latin America make region as a variable stand out causing a need for further analysis by region. The results of both the correlation analysis and the regression analysis in Table 4 make it clear that tourism has a differential effect across regions. Further analysis is needed on all three regions to understand the effect of tourism on development in the developing world. To conduct this analysis, three more regressions were run filtering the data by region, and the results are presented below.

Table 5 presents the results of regression analysis filtering for only cases in Africa, and thus the regressions in Table 5 involve much smaller sample sizes than seen in Table 4. Many of the statistically significant results from the regressions in Table 4 remained significant, but with some changes. In the full model of Table 4, tourism had a statistically significant effect on poverty, however, when the data is filtered for only Africa, the coefficient loses its significance 
and tourism has no effect on poverty. Another important change from the full data set to the regression filtered for Africa is that tourism has a statistically significant effect on HDI. This result supports the hypothesis that tourism leads to development by showing that as tourism increases, so does quality of life in Africa.

Research by Christie, et. al (2014) and published by The World Bank provides some key insight into the success of tourism in Africa through an in depth case study analysis of tourism in 24 countries in varying parts of the world. Several factors stand out in the cases of the African nations that set it apart from the other cases in the book. In Africa, tourism development involves significant public involvement and it is clear that the public is treated as a key stakeholder in tourism. In the cases of South Africa and Kenya, public-private partnership models assisted in optimum use of international funds and kept the focus and priorities in line with locals (Christie, et.al 2014). In Rwanda, the Sabyinyo Silverback Lodge area presents an incredibly unique model where the community owns key tourism assets; funds collected from the asset and bed nights are collected in a community trust. The trust is managed and dispersed locally putting the funds into community projects and dispersing dividends by households, which literally puts the money from tourism into the hands of locals (Christie, et. al 2014, 259). Mount Killimanjaro is a substantial source of revenue and tourism interest in Tanzania, and the management plan for it was developed with public input sessions with the goal of "ensuring public interest, cultural traditions, and community surroundings were respected" (Christie, et. al 2014, 270). The propoor model of encouraging locals to start businesses and be involved in the tourism industry was used in the case of Tunisia. The government of Tunisia started a program to encourage young people to move into tourism management positions and encouraged entrepreneurship in the 
sector intentionally when the country decided to make tourism a focus (Christie, et. al 2014, 275).

In another World Bank study, “Tourism Product Development: Interventions and Best Practices in Sub-Saharan Africa”, very similar success factors are identified when analyzing tourism in Africa. The report identifies seven factors that allow for tourism to sustainably scale up: paradigm shift in policy on land tenure and natural resources, concessions and joint-venture partnerships, evaluating and enhancing market linkages, shifting brands with promotion and investment, adaptions in livelihood strategies for hosts, partnerships between agencies, and close networks of industry professionals (Spenceley 2010, 31). Collaboration and partnerships with local people are also factors in nearly every case used in the study (Namibia, Tanzania, Seychelles, Zanzibar, and Mali). Vocational training to produce high quality hospitality professionals is identified as a key success factor for tourism in Kenya, which benefits the locals in those positions as they are equipped to make higher wages in the sector (Spenceley 2010, 29). It makes a great deal of sense that these factors would produce the statistical result observed in this study, because Africa takes a very intentional approach to tourism where development and benefit to the destination is inherent in the industry's goals and purpose.

Labor force participation's effect on poverty remained significant and positive, and labor force participation's effect on HDI remained significant and negative. This supports the explanation presented above based on the findings of Kinyondo and Pelizzo (2015) that low wage tourism jobs cause the emergence of the working poor. The strength of the positive effect of labor force participation on poverty grew from the result in the full data set though, which means that for one unit of change in labor force, poverty will grow more in Africa than in other regions. Kinyondo and Pelizzo's (2015) study in Tanzania used data from the National Bureau of 
Statistics and showed that "no single group of workers from any other sector in Tanzania's economy is paid less than those employed in tourism" (75). Their theory would explain and be supported by this result that low wage, low skill jobs contribute to increases in labor force participation but not decreases in poverty or increases in quality of life. Because labor force participation represents jobs in all sectors of the economy and not just in tourism, this logic isn't a perfect explanation for the result. It is supported, however by data on service and tourism jobs in Africa. According to the World Bank, one in 20 jobs in Sub-Saharan Africa is in travel and tourism (Christie et. al 2014). World Bank Data also shows that employment in the service sector in Sub-Saharan Africa is $31.45 \%$ (World Bank, The). Another report is quoted saying that "the service sector is increasingly absorbing Africa's labor force" (Sow 2017). It would also make sense that the effect would be stronger in Africa than other regions because tourism represents a larger percent of the economy in Africa. Therefore, logic would follow that there would be more jobs in the tourism sector in Africa than in other regions. If Kinyondo and Pelizzo (2015) are correct, then Africa would also have more low wage jobs and working poor citizens with a lower quality of life than other regions.

Foreign aid continued to have a significant effect on HDI in Africa and in the same negative direction as the full data set. However, foreign aid lost its statistically significant effect on poverty when the research scope became limited to Africa. Population density also continues to show a statistically significant effect on HDI and have a very small regression coefficient. 
Table 5: Regression of Poverty, Inequality and Quality of Life on Tourism and Other Explanatory Variables in Africa

\begin{tabular}{|l|l|l|l|}
\hline Independent Variables & \multicolumn{1}{|c|}{ Poverty } & \multicolumn{1}{c|}{ Gini } & \multicolumn{1}{c|}{ HDI } \\
\hline Tourism & $\begin{array}{l}-.947 \\
(.979)\end{array}$ & $\begin{array}{l}.697 \\
(.701)\end{array}$ & $\begin{array}{l}.010^{* * *} \\
(.003)\end{array}$ \\
\hline Labor Force & $1.019 * * *$ & .190 & $-.002^{*}$ \\
Participation & $(.211)$ & $(.136)$ & $(.001)$ \\
\hline Education & -.291 & -.127 & -.002 \\
& $(497)$ & $(.349)$ & $(.002)$ \\
\hline Foreign Aid & .251 & -.426 & $-.005^{* * *}$ \\
& $(.327)$ & $(.227)$ & $(.001)$ \\
\hline \multirow{2}{*}{ Welfare } & 1.855 & 1.533 & .006 \\
& $(1.772)$ & $(1.155)$ & $(.008)$ \\
\hline Population Density & -.009 & -.015 & $.000^{*}$ \\
& $(.016)$ & $(.011)$ & $\left(9.73^{\mathrm{E}-6}\right)$ \\
\hline Adjusted R & .623 & .005 & .556 \\
\hline Number of Cases & 28 & 26 & 40 \\
\hline
\end{tabular}

Note: Standard errors are in parentheses.

$* \mathrm{P}<0.05, * * \mathrm{P}, 0.01, * * * \mathrm{P}<0.001$

When the data is filtered for Asia and Oceania, as shown in Table 6, only one variable has a statistically significant effect on a dependent variable. Tourism did not return any statistically significant results for the dependent variables, therefore, tourism is found to have no effect on poverty, Gini, and HDI. The low $\mathrm{R}^{2}$ value of the models for Asia and Oceania indicates that the model is weak and may contribute to the lack of significant data in this data set. Foreign aid is found to have a statistically significant and positive effect on poverty and a negative effect on HDI, meaning that increases in foreign aid cause poverty to increase and quality of life to decrease. The body of literature reference by Asongu and Nwachukwu (2017) again explains the result. This group of scholars challenge the notion that foreign aid has a positive effect on development. The result found here would support their argument that foreign aid does not have a positive effect on development. 
Table 6: Regression of Poverty, Inequality and Quality of Life on Tourism and Other Explanatory Variables in Asia \& Oceania

\begin{tabular}{|l|l|l|l|}
\hline Independent Variables & \multicolumn{1}{|c|}{ Poverty } & \multicolumn{1}{c|}{ Gini } & \multicolumn{1}{c|}{ HDI } \\
\hline Tourism & -.121 & .077 & .000 \\
& $(.237)$ & $(.145)$ & $(.001)$ \\
\hline Labor Force & .023 & .006 & -.001 \\
Participation & $(.164)$ & $(.106)$ & $(.001)$ \\
\hline \multirow{2}{*}{ Education } & -.439 & -.275 & .000 \\
& $(.573)$ & $(.348)$ & $(.005)$ \\
\hline Foreign Aid & $.497 *$ & -.018 & $-.004 *$ \\
& $(.146)$ & $(.138)$ & $. .002)$ \\
\hline Welfare & -.852 & .455 & -.004 \\
& $(1.032)$ & $(.754)$ & $(.011)$ \\
\hline \multirow{2}{*}{ Population Density } & -.007 & -.004 & $7.719^{\mathrm{E}-5}$ \\
& $(.007)$ & $(.004)$ & $(.000)$ \\
\hline Adjusted R ${ }^{2}$ & .352 & -.268 & .131 \\
\hline Number of Cases & 24 & 24 & 33 \\
\hline
\end{tabular}

Note: Standard errors are in parentheses.

$* \mathrm{P}<0.05, * * \mathrm{P}, 0.01, * * * \mathrm{P}<0.001$

Similar, to the previous tables, Table 7 shows the full model regression but filters for only countries in Latin America. The regressions between the independent and dependent variables in Latin America produced no statistically significant results. The sample sizes of this region are very small, which is likely a contributing factor to the absence of any significant data. This will be treated as no result in the case of Latin America. The results from the regressions in Latin America can be found in Table 7. 
Table 7: Regression of Poverty, Inequality and Quality of Life on Tourism and Other Explanatory Variables in Latin America

\begin{tabular}{|l|l|l|l|}
\hline Independent Variables & \multicolumn{1}{|c|}{ Poverty } & \multicolumn{1}{c|}{ Gini } & \multicolumn{1}{c|}{ HDI } \\
\hline Tourism & -.033 & -.143 & .000 \\
$(.288)$ & $.584)$ & $(.003)$ \\
\hline Labor Force & .085 & .298 & -.003 \\
Participation & $(.204)$ & $(.414)$ & $(.003)$ \\
\hline Education & .147 & .478 & -.005 \\
& $(.254)$ & $(.514)$ & $(.004)$ \\
\hline Foreign Aid & .443 & -.939 & -.018 \\
& $(.656)$ & $(1.328)$ & $(.005)$ \\
\hline Welfare & -.509 & .649 & -.003 \\
& $(.667)$ & $(1.351)$ & $(.011)$ \\
\hline Population & -.001 & .000 & $1.521^{\mathrm{E}-5}$ \\
& $(.002)$ & $(.003)$ & $(.000)$ \\
\hline Adjusted $\mathbf{R}^{2}$ & .124 & -.573 & .372 \\
\hline Number of Cases & 14 & 14 & 17 \\
\hline
\end{tabular}

Note: Standard errors are in parentheses.

$* \mathrm{P}<0.05, * * \mathrm{P}, 0.01, * * * \mathrm{P}<0.001$

\section{Summary of the Findings}

The quantitative analysis in this chapter shows support for the hypothesis that tourism can have a positive effect on the development of destinations. The initial correlation analysis showed the first support for the hypothesis by showing significant results for the relationship between tourism and poverty as well as tourism and HDI that were in alignment with the hypothesis. The regression analysis of the full data set of about 141 developing countries continued to provide support for the hypothesis through the statistically significant effect that tourism had on poverty. The initial results also showed clear support for the fact that tourism has a differential effect across regions. This finding led to further regression analysis of the data isolating the effects of tourism on development in each region. Africa did provide statistically significant evidence of the effect of tourism on development that provided additional support for 
the hypothesis. Specifically, in Africa, tourism had a statistically significant and positive effect on HDI. However, the absence of significant results for tourism in Asia and Oceania and in Latin America did not provide any further information for or against the hypothesis.

This case built by the significant results throughout the correlation and regression analysis will lead to the rejection of the null hypothesis that tourism has no effect on development. Instead the quantitative results provide support for the hypothesis and evidence that tourism causes development in developing regions. 


\section{CHAPTER V: CONCLUSION}

This thesis addressed the question of whether tourism is an effective tool for development by evaluating the effectiveness of using tourism to reduce poverty, ameliorate inequality, and promote quality of life in destination countries. Three research questions were used to evaluate the question: 1) Is tourism development an effective tool for poverty alleviation? 2) Is tourism development an effective tool in reducing income inequality? 3) Is tourism development effective for improving quality of life? While the depth of meaningful quantitative research in this area is somewhat small, this study builds on the findings in the literature linking tourism to the development indicators of poverty, inequality, and quality of life. It also contributes to the literature with the finding that tourism effects development differently based on the region of the country.

To evaluate the research question, the study used OLS regression of lagged independent variables for around 100 countries in the developing world. The study utilized secondary data collected from The World Bank and United Nations. Control variables of labor force participation, education, foreign aid, welfare, and population density were included to isolate the relationship between the key independent variable, tourism, and the dependent variables of the poverty headcount ratio, Gini, and HDI.

\section{Main Findings}

The study concluded by finding that in developing regions, tourism does lead to higher development through a reduction in poverty in the full data set and an increase in quality of life for African countries. The result of poverty having a significant result in the regression of the full model supports arguments by Jiang et al. (2011) who found evidence that higher intensity 
tourism industries also show less poverty on average, an argument that this hypothesis is based on. There were no statistically significant findings on the relationship between tourism and inequality. This supports the arguments presented in Chapter II that tourism's impact on inequality will be small. This is also consistent with the argument that inequality is unlikely to change from economic growth alone and needs to be strategically targeted to change (Azerad and Hederman, 2016; McElwee, 2016).

The strongest results came from African nations as a region. Africa also had the highest levels of poverty and inequality and lowest quality of life starting out of all the regions in the study. Tourism's effect on quality of life was strong and statistically significant in Africa. These results are in strong agreement with Jiang, DeLacy, Harrison and Mkiramweni (2011) and Biagi, et. al (2015) that tourism has a direct and positive impact on improving quality of life.

Based on the evidence provided, the findings partially support the hypothesis that tourism leads to development through decreased poverty and improved quality of life. The findings are also interesting and somewhat unique in the discovery of different results by region. While the theory is far from perfect, the results also support modernization theory. Modernization theory's main tenant is that economic growth causes development and causes modernization. In the case of this study, tourism as a percent of GDP is a measure of economic growth and it was found to cause development through decreased poverty and increased quality of life in Africa. The literature review references Telfer (2015)'s idea that focus on mass tourism over the last couple of decades has made modernization "the implicit base for many studies on tourism in developing countries" (41). Presumably, mass tourism makes up the majority of economic tourism activity, therefore, this study's data focuses on mass tourism. This makes a clear argument for why the results would support modernization theory. 
While these findings only partially support the hypothesis, the story produced by the data does lead to many questions and potential directions for future research.

\section{Limitations \& Recommendations for Future Research}

Tourism operates differently in almost every market in which it exists. Cultures, histories, norms, and economies differ in each market which contributes to differences in tourism operations. Data in the field of tourism is scarce and for the most part only available on the national level. This makes quantitative research on the regional or local level extremely difficult and drives the need for proxies to measure key concepts. The lack of data forces studies like this one to analyze tourism and development on a macro-level making broad, sweeping generalizations which may not apply entirely destination by destination. Quality of the results are also dependent on the quality of the data collected, and the study is limited in the data collected by individual nations. Reporting can also be inaccurate when nations collect their own data and then report it to multi-national organizations, which is where data for this study comes from. The data on tourism may be flawed in it's bias towards mass tourism. As previously stated in this chapter, tourism data is skewed toward mass tourism simply because mass tourism is presumably the largest share of the tourism receipts. A dependency theorist would likely criticize this about the industry and find issue with the bias tourism mass consumption and modernization in this study. All of these potential flaws in the data impact the quality of the results.

Another potential flaw in the data has to do with HDI, the metric used for quality of life. HDI is potentially a weak indicator for quality of life. The composite statistic includes income per capita, and it has been openly criticized for its inclusion of income in the metric. Utilizing HDI to measure quality of life may also be problematic because its limited scope of quality of 
life excludes tourism's effect on environment, resources, and culture, amongst other things. Other areas of tourism research explore these topics in depth, and future researchers should think about how to include them into the study of tourism's effect on quality of life.

Thorough and accurate control variables are key to isolating the relationship between the independent and dependent variables. There was not enough available data for several possible control variables, so they were not included. Crime is one of these variables that was referenced in the literature by Schubert (2010) and Biagi and Detotto (2014) as possibly affecting quality of life; however, there was not enough data accessible to include it in the study. Future studies should try to include this variable. It would also be beneficial for future studies to investigate whether or not larger quantities of people living in poverty, in situations of high inequality, and experiencing low quality of life makes deriving benefit from tourism easier. It is possible that if few people in a destination are experiencing such conditions, it may take more effort for the benefit to reach them.

One of the biggest flaws in this study is the years of the data. The independent variable of tourism was represented as an average of data from 2005 to 2009. 2008 marked the beginning of what became a global recession with the bursting of the real estate bubble in the United States. The dependent variables were all represented as averages of data from 2010 to 2014, and by this time period, the Great Recession was global. Thus, it is likely that poverty and inequality would be higher in 2010-2014 than it was from 2005-2009 and quality of life would be lower as a result of the recession. This is not taken into account in this data analysis, so relationships between tourism and the dependent variables could be misrepresented simply as a matter of timing of the data snapshots. Future studies should rerun the tests in different years taking into account the state of the global economy. The most accurate results would be found at a time when the state 
of the global economy is similar in both five year periods. Future researchers should continue to investigate the finding that tourism has different effects in different regions. This could be done by studying the difference between the effects of tourism in the developing versus the developed world.

For future studies, a mixed method approach that combines quantitative and qualitative research techniques is recommended to enhance the reliability of the findings and make them more widely applicable as theory. Eisenhardt (1989) supports mixed-method studies saying that “...the triangulation made possible by multiple data collection methods provides stronger substantiation of constructs and hypotheses" (538). Furthermore, there is great strength in combining qualitative and quantitative methods since they compliment each other greatly. Quantitative analysis can make clear relationships that exist between variables without the risk of the researcher being distracted by the story that may be presented anecdotally. Qualitative analysis then allows for theory building and "is useful for understanding the rationale or theory underlying relationships revealed in the quantitative data..." (Eisenhardt 1989, 538). Qualitative research and analysis can fill in some of the gaps left by the data. In fact, some economists warn of the dangers of using only economic data as the key to development. Nobel prize winning economist Joseph Stiglitz (2002) has openly criticized organizations such as The World Bank, International Monetary Fund, and the World Trade Organization for offering "single prescriptions", not seeking "alternative prescriptions" as well as offering up "simplistic models of market economy" (Mowforth and Munt 2015, 46). Economist Hernando de Soto (2001) echoed the concerns put forth by Stiglitz (2002) saying that "development is a complex and messy business requiring careful local analysis (in a spurious analogy to modern medicine he 
coins 'clinical economics')" (Mowforth and Munt 2015, 46). The qualitative study will also allow for a more localized level of analysis than national like de Soto (2001) calls for.

To minimize the aforementioned limitations of quantitative analysis, it is recommended to follow it with a qualitative analysis of tourism development's effects on poverty, inequality, and quality of life. Due to the significant results in correlations in Africa in this study, a crosscase style of qualitative analysis is recommended to analyze the significant results in Africa. This style of inquiry is related to case study research and holds great merit in the literature. According

to Bromley (1990), case studies are a "systematic inquiry into an event or a set of related events which aims to describe and explain the phenomenon of interest" (302). Similarly, Eisenhardt (1989) described the case study as "a research strategy which focuses on understanding the dynamics present within single settings" (534). The cross-case method of qualitative analysis allows for real world perspective and a more holistic analysis of phenomena by comparing single settings within a region (Yin 2017, 5), in this case the region of Africa. More specifically, case study analysis would allow the researcher to look at several cases within a region to better understand the phenomenon of tourism positively impacting development indicators. Using cross-case analysis, patterns and concepts will be able to be identified and theories developed across several cases. Proponents for cross-case analysis say that it is a tool that mitigates discrete cases and assists the researcher in constructing theories and explanations for phenomena (Khan and VanWynsberghe 2008).

\section{Significance of the Study}

The results of this study have implications for national and international policy makers, and show that tourism can drive the results desired by the Sustainable Development Goals set by 
the United Nations discussed in Chapter 1. Policy makers should first and foremost, make sure that they continue to analyze the data and know how policy will act in their region. For example, policy makers in Latin America should not assume or expect tourism to have an impact on quality of life. Africa, however, should know that tourism affects quality of life in their region. For this same reason, it important that regions not copy policies from one another without careful analysis of how the policy may work differently in their region. The results also have implications on how policies could affect the development indicators. Poverty had a small and significant result in the full data set, but did not remain significant in any individual region. This may suggest that tourism has the potential to effect poverty on its own, but that pairing it with techniques strategically positioned to affect poverty, such as pro-poor tourism strategies, may have a stronger result. Again, policy makers should analyze the potential effect for their region before moving forward. If reducing inequality is a desired result and indicator of development, the literature and statistical results agree that it will not happen on its own. Tourism efforts must be incredibly pointed and well designed in order to impact inequality. Far less theories and techniques exist than to impact inequality with tourism than poverty, so policy makers will need to be innovative to have an impact in this area. The result of tourism on quality of life is completely dependent on region and only showed significant results in individual regions, Africa in particular. The literature on quality of life indicates that resident perceptions of tourism may be a strong indicator of how tourism will effect development in the region. Campaigns to positively impact public perception of tourism may have the most impact in this area.

The findings of this study stir up as many new questions as answers. However, it brings great contribution to the literature by finding that tourism has different effects in different regions, a topic not directly or strongly addressed in the existing literature. This research has 
implication for the use of tourism in developing nations because it proves that the desired effect for tourism and quality of life are possible. This thesis also leads us to ask what makes tourism so effective for development in Africa. The answers to those questions could serve as a playbook for effective use of tourism as a tool for development by practitioners in the future. 


\section{REFERENCES}

Alam, Md S., and Sudharshan R. Paramati. 2016. "The Impact of Tourism on Income Inequality in Developing Economies: Does Kuznets Curve Hypothesis Exist?" Annals of Tourism Research 61:111-26.

Andereck, K. L., and G. P. Nyaupane. 2011. "Exploring the Nature of Tourism and Quality of Life Perceptions among Residents." Journal of Travel Research 50:248-60.

Andereck, K. L., K. M. Valentine, C. A. Vogt, and R. C. Knopf. 2007. "A Cross-Cultural Analysis of Tourism and Quality of Life Perceptions. Journal of Sustainable Tourism, 15, 483-502." Journal of Sustainable Tourism15:483-502.

Ap, J., (1990). Residents' perceptions research on the social impacts of tourism. Annals of Tourism Research, 17, 610-616.

Archer, Brian, and John Fletcher. 1996. "The Economic Impact of Tourism in the Seychelles." Annals of Tourism Research 23 (1):32-47.

Ashley, Caroline, and J. Ashton. 2006. "Can the Private Sector Mainstream Pro-Poor Tourism? id21insights 62, 3." Id2 linsights 62:3.

Ashley, Caroline and Dilys Roe. 2002. "Making Tourism Work for the Poor: Strategies and Challenges in Southern Africa." Development Southern Africa 19 (1) (March): 61.

Ashley, Caroline, D. Roe and H. Goodwin. 2001. Tourism strategies: Making tourism work for the poor: A review of experience. London: Overseas Development Institute.

Asongu, Simplice A., and Jacinta C. Nwachukwu. 2017. "Foreign Aid and Inclusive Development: Updated Evidence from Africa, 2005-2012*." Social Science Quarterly 98 (1) (March):282-98. 
Azerrad, David, and Rea S. Hederman Jr. 2016. "The Misguided Focus on Income Inequality." In Opposing Viewpoints: Income Inequality, Anonymous. Farmington Hills, MI: Greenhaven Press, 168.

Biagi, Bianca, D. Lambiri, and A. Faggian. 2012. "The Effect of Tourism on the Housing Market." In Handbook of Tourism and Quality-of-Life Research,Anonymous : Springer, 635-652.

Biagi, Bianca, and C. Detotto. 2014. "Crime as Tourism Externality." Regional Studies 48 (4):693-709.

Biagi, Bianca, Maria G. Ladu, and Vicente R. Royuela. 2015. "Human development and Tourism specialization. Evidence from a panel of developed and developing countries." Research Institute of Applied Economics and Regional Quantitative Analysis Research Group.

Blake, Adam, Jorge Saba Arbache, M. Thea Sinclair, and Vladamir Teles. 2008. "Tourism and Poverty Relief." Annals of Tourism Research 35 (1) (January):107-126.

Booyens, Irma, and Christian M. Rogerson. 2016. "Tourism Innovation in the Global South: Evidence from the Western Cape, South Africa." International Journal of Tourism Research 18 (February):515-24.

Britton, Stephen G. 1982a. "International Tourism and Multinational Corporations in the Pacific: The Case of Fiji." In The Geography of Multinationals, eds. M. Taylor, N. Thrift. London: Croom Helm, 252-274.

Britton, Stephen G. 1982b. "The Political Economy of Tourism in the Third World." Annals of Tourism Research 9 (3):331-358. 
Bromley, D. B. 1990. "Academic Contributions to Psychological Counselling: I. A Philosophy of Science for the Study of Individual Cases." Counselling Psychology Quarterly 3 (3):297307.

Cater, Erlet A. 1987. "Tourism in the Least Developed Countries." Annals of Tourism Research 14 (2):202-26.

Christie, Iain, Eneida Fernandes, Hannah Messerli, and Louise Twining-Ward. 2014. Tourism in Africa : Harnessing Tourism for Growth and Improved Livelihoods. Washington, D.C.: World Bank Publications.

Clancy, M. 2001. Exporting Paradise: Tourism Development in Mexico. Bingley: Emerald Group Publishing Limited.

Costanza, Robert, Brendan Fisher, Saleem Ali, Carline Beer, Lynne Bond, Roelof Boumans, Nicholas L. Danigelis. 2008. "An Integrative Approach to Quality of Life Measurement, Research, and Policy" S.A.P.I.EN.S. 1 (1).

De Janvry, Alain, and Elisabeth Sadoulet. 2016a. Development Economics: Theory and Practice. Routledge.

De Janvry, Alain, and Elisabeth Sadoulet. 2016b. "Inequality and Inequity." In Development Economics: Theory and Practice, Anonymous. New York, NY: Routledge, 248.

Deery, M., L. Jago, and L. Fredline. 2012. "Rethinking Social Impacts of Tourism Research: A New Research Agenda." Tourism Management 33 (1):64-73.

Desai, Vandana, Robert B. Potter, eds. 2014. The Companion to Development Studies. London, UK: Routledge.

Devereux, Stephen. 2001. "Sen's Entitlement Approach: Critiques and CounterCritiques." Oxford Development Studies 29 (3). 
Dritsakis, Nikolaos. 2004. "Tourism as a Long-Run Economic Growth Factor: An Empirical Investigation for Greece using Causality Analysis." Tourism Economics 10 (3):316.

Durbarry, Ramesh. 2004. "Tourism and Economic Growth: The Case of Mauritius." Tourism Economics 10 (4):389-401.

Eisenhardt, Kathleen M. 1989. "Building Theories from Case Study Research." The Academy of Management Review 14 (4) (October):532-50.

Eugenio-Martin, Juan L., Noelia M. Morales, and Riccardo Scarpa. 2004. "Tourism and Economic Growth in Latin American Countries: A Panel Data Approach." Fondazione Eni Enrico Mattei. 26 (February).

Figini, P., M. Castellani, and L. Vici. 2009. "Estimating Tourism Effects on Residents: A Choice Modeling Approach to the Case of Rimini." In Advances in Tourism Economics. New Developments, Anonymous . Berlin: Springer-Verlag, 145-164.

Fletcher, John. 1989. "Input-Output Analysis and Tourism Impact Studies." Annals of Tourism Research 16 (4):514-29.

Frank, A. G. 1967. Capitalism and Underdevelopment in Latin America. New York: Monthly Review Press.

Greenwood, Daphne T., and Richard P. F. Holt. 2010. Local Economic Development in the 21st Century: Quality of Life and Sustainability. Armonk, NY: M.E. Sharpe, Inc.

Goulet, Denis. 1971. The Cruel Choice: A New Concept on the Theory of Development. New York: Atheneum.

Göymen, K. (2000). “Tourism and governance in Turkey.” Annals of Tourism Research 27 (4):1025-1048. 
Haddad, E. A., A. Porsse, and W. Rabahy. 2013. Domestic tourism and regional inequality in Brazil. Tourism Economics 19(1):173-186.

Harrison, David. 1992. "International Tourism and the Less Developed Countries: The Background." In Tourism and the Less Developed Countries, ed. David Harrison. Toronto: Bellhaven, 1-18.

Hettne, Bjorn. 1995. Development Thory and the Three Worlds: Towards an International Political Economy of Development. London, UK: Harlow.

Holden, Andrew, J. Sonne, and M. Novelli. 2011. "Tourism and Poverty Reduction: An Interpretation by the Poor of Elmina, Ghana." Tourism Planning and Development 8 (3):317-34.

Huse, M., T. Gustavsen, and S. and Almedal. 1998. "Tourism Impact Comparisons among Norwegian Towns." Annals of Tourism Research 25 (3):721-38.

Incera, A. C., and M. F. Fernández. 2015. "Tourism and Income Distribution: Evidence from a Developed Regional Economy." Tourism Management 48:11-20.

Ivanov, Stanislav, and Craig Webster. 2007. "Measuring the Impact of Tourism on Economic Growth." Tourism Economics 13 (3):379-88.

Ivlevs, A. 2016. "Happy Hosts? International Tourist Arrivals and Residents' Subjective Wellbeing in Europe." Journal of Travel Research 56 (5):599-612.

Jafari, J. 1977. "Editor's Page." Annals of Tourism Research 5 (1):8.

Jenkins, C. L. 1982. "The Effects of Scale in Tourism Projects in Developing Countries." Annals of Tourism Research 9:229-49.

Jiang, Min, Terry DeLacy, David Harrison and Peter Mkiramweni. 2011. "Some Evidence for Tourism Alleviating Poverty." Annals of Tourism Research 38 (3) (July):1181. 
Kakwani, Nanuk, and Ernesto Pernia. 2000. "What is Pro-Poor Growth?." Asian Development Review 18 (1):1-16.

Kemper, R. 1979. "Tourism in Toas and Patzcuaro: A Comparison of Two Approaches to Regional Development." Annals of Tourism Research 6 (1):91-110.

Khan, Maryam M. October 1997. "Tourism Development and Dependency Theory: Mass Tourism Vs. Ecotourism." Annals of Tourism Research 24 (4):988-991.

Khan, Samia, and Robert VanWynsberghe. 2008. "Cultivating the Under-Mined: Cross-Case Analysis as Knowledge Mobilization." Forum: Qualitative Social Research 9 (1).

Kim, Hyun J., Ming-Hsiang Chen, and SooCheong Jang. 2006. "Tourism Expansion and Economic Development: The Case of Taiwan." Tourism Management 27 (5):925-33.

Kinyondo, Abel, and Riccardo Pelizzo. 2015. "Tourism, Development, and Inequality: The Case of Tanzania." Poverty and Public Policy 7 (1):64-79.

Krakover, S. 2004. Tourism development—centres versus peripheries: The Israeli experience during the 1990s. International Journal of Tourism Research 6 (2):97-111.

Laws, Eric. 2009. "Book Review: ‘ProPoor Tourism - Who Benefits?' Perspectives on Tourism and Poverty Reduction' in Current Themes in Tourism. Clevedon: Channel View." Tourism Management 30:143-5.

Lea, John. 1988. Tourism and development in the third world. London: Routledge.

Lee, Sangkwon, and J. T. O’Leary. 2008. "Determinants of Income Inequality in Us Nonmetropolitan Tourism-and Recreation-Dependent Communities." Journal of Travel Research 46 (4):456-68.

Lee, Sangkwon. 2009. "Income Inequality in Tourism Services-Dependent Counties." Current Issues in Tourism 12 (1):33-45. 
Li, Hengyun, C. Goh, H. Zhang Qiu, and F. Meng. 2015. "Effect of Tourism on Balanced Regional Development: A Dynamic Panel Data Analysis in Coastal and Inland China." Asia Pacific Journal of Tourism Research 20 (6):694-713.

Li, Hengyun, J. L. Chen, G. Li, and C. Goh. 2016. Tourism and regional income inequality: Evidence from china. Annals of Tourism Research 58:81-99.

Lindberg, K., T. D. Andersson, and B. G. C. Dellaert. 2001. "Tourism Development. Assessing Social Gains and Losses." Annals of Tourism Research 28:1010-30.

Marrocu, E., and R. Paci. 2011. "They Arrive with New Information. Tourism Flows and Production Efficiency in the European Regions." Tourism Management 32:750-8.

Massidda, C., and I. Etzo. 2012. The determinants of Italian domestic tourism: A panel data analysis. Tourism Management 33(3):603-610.

Mathieson, A., and G. Wall. 1982. Tourism: Economic, Physical and Social Impacts. Harlow: Longman.

McElwee, S. 2016. "Inequality is a problem for middle-class and low income workers." In Opposing viewpoints: Income inequality. Farmington Hills, MI: Greenhaven Press, 47. Mitchell, J. and Ashley, C. 2007. "Pathways to prosperity: How can tourism reduce poverty?" Draft Report Overseas Development Institute and World Bank.

Mitchell, Jonathan, Jodie Keane and Jenny Laidlaw. 2009. Making success work for the poor: Package tourism in northern tanzania. Overseas Development Institute; SNV, Final Report.

Moufakkir, O., and Y. Reisinger. 2012. The Host Gaze in Global Tourism. Wallingford: CABI Publishing. 
Mowforth, Martin, and Ian Munt. 2014. Tourism and Sustainability: Development, Globalization and New Tourism in the Third World. Oxon: Routledge.

Nevin, Tom. 2007. "What is Pro-Poor Tourism?" African Business (November):50.

Nunkoo, R., and D. Gursoy. 2012. "Residents' Support for Tourism: An Identity Perspective." Annals of Tourism Research 39 (1):243-68.

Opperman, M. 1992. "International Tourism and Regional Development in Malaysia." Tijdschrift Voor Econ. En Soc. Geographie 83 (3):226-33.

Papatheodorou, A. 2004. "Exploring the Evolution of Tourism Resorts." Annals of Tourism Research 31 (1):219-37.

Perroux, F. 1955. "Note Sur La Notion De Poles Croissance." Economic Appliquee 1 and 2:30720.

Pi-Sunyer, O. 1989. "Changing Perceptions of Tourism and Tourists in a Catalan Resort Town." In Hosts and Guests: The Anthropology of Tourism (2nd Edn), ed. V. Smith. Philadelphia: University of Pennsylvania Press, 187-199.

Potter, Robert B. 2014a. “The Nature of Development Studies.” In The Companion to Development Studies, eds. Vandana Desai, Robert B. Potter. London, UK: Routledge, 16-20.

Potter, Robert B. 2014b. "Theories, Strategies and Ideologies of Development." In The Companion to Development Studies, eds. Vandana Desai, Robert B. Potter. London, UK: Routledge, 83-87.

Proenca, S., \& Soukiazis, E. 2008. Tourism as an economic growth factor: A case study for southern European countries. Tourism Economics 14(4): 791-806. 
Przeworski, Adam, and Fernando Limongi. 1997. "Modernization: Theories and Facts." World Politics 49 (2):155-83.

Reisinger, Y. 2015. Transformational Tourism: Host Perspectives. Wallingford: CABI Publishing.

Rostow, Walt W. 1960. The Stages of Economic Growth: A Non-Communist Manifesto. Cambridge: Cambridge University Press.

Rostow, Walt W. 1967. The Stages of Economic Growth: A Non-Communist Manifesto. Cambridge: Cambridge University Press.

Scheyvens, Regina. 2015. "Tourism and Poverty Reduction." In Tourism and development: Concepts and issues 2nd edition, eds. Richard Sharpley, David J. Telfer. 2015: Channel View Publications, 118.

Scheyvens, Regina, and J. H. Momsen. 2008. "Tourism and Poverty Reduction: Issues for Small Island States." Tourism Geographies 10 (1):22-41.

Schmidt, H. 1989. "What Makes Development." Development and Cooperation 6:19-26.

Schubert, S. F. 2010. "Coping with Externalities in Tourism - A Dynamic Optimal Taxation Approach." Tourism Economics 16 (2):321-43.

Seckelmann, A. 2002. "Domestic tourism—a Chance for Regional Development in Turkey?" Tourism Management 23 (1):85-92.

Sen, Amartya. 1983. "Development: Which Way Now?" Economic Journal (December).

Sen, Amartya. 1987. Commodities and Capabilities. New Delhi: Oxford University Press.

Sen, Amartya. 1993. "Capability and Well-being." In The Quality of Life, eds. Martha Nussbaum, Amartya Sen. Oxford: Clarendon Press. 
Sen, Amartya. 1999. Development as Freedom: Human Capability and Global Need. New York: Knopf.

Sharpley, Richard. 2014. "Host Perceptions of Tourism: A Review of the Research." Tourism Management 42:37-49.

Sharpley, Richard, and David J. Telfer. 2015. Tourism and Development: Concepts and Issues. Tonawanda, NY: Channel view Publications

Smith, Stephen L. J. 1995. Tourism Analysis: A Handbook. Essex, England: Addison Wesley Longman Limited.

Sow, Mariama. 2017. "Figures of the Week: Sub-Saharan Africa's Labor Market in 2017." (January 11).

Spenceley, Anna. 2012. Tourism product development interventions and best practices in subsaharan africa: Part 1: Synthesis. The World Bank.

Stiglitz, Joseph E. 2002. Globalization and its Discontents. W.W. Norton \& Company.

"Sustainable Development Goals." August.

https://www.un.org/sustainabledevelopment/sustainable-development-goals/.

Telfer, David J. 2015. "The Evolution of Development Theory and Tourism." In Tourism and Development: Concepts and Issues (2nd Edn), eds. Richard Sharpley, David J. Telfer. Bristol, Buffalo, Toronto: Channel View Publications, 31-73.

Thirlwall, A. P. 2014. "Development and Economic Growth." In The Companion to Development Studies, eds. Vandana Desai, Robert B. Potter. London, UK: Routledge, 2528.

"Tourism for SDG's." August. http://tourism4sdgs.org/ . 
UNDP. 2013. Human development report 2013: The rise of the south: Human progress in a diverse world. See http://hdr.undp.org/en/media/HDR2013_EN_Summary.pdf.

Vanhove, N. 2005. "The economic impact of tourism." The economics of tourism Destinations (pp. 169). Burlington, MA: Elsevier Limited.

Ward, C., and T. Berno. 2011. "Beyond Social Exchange Theory: Attitudes Towards Tourists." Annals of Tourism Research 38:1556-69.

Wearing, S. 2001. Volunteer Tourism: Experiences that make a Difference. Wallingford: CABI Publishing.

White, Howard. 2014. "The Measurement of Poverty." In The Companion to Development Studies, eds. Vandana Desai, Robert B. Potter. London, UK: Routledge, 60-67.

Woo, E., H. Kim, and M. Uysal. 2015. "Life Satisfaction and Support for Tourism Development." Annals of Tourism Research 50 (1):84-97.

World Bank, The. Employment in Services (\% of Total Employment) (Modeled ILO Estimate) [Data file and code book]. Retrieved from https://data.worldbank.org/indicator/SL.SRV.EMPL.ZS?name_desc=false.

Yin, Robert K. 2017. Case Study Research and Applications: Design and Methods. Los Angeles: Sage.

Yu, Chia-Pin, H. Chancellor, and S. T. Cole. 2011. "Examining the Effects of Tourism Impacts on Resident Quality of Life: Evidence from Rural Midwestern Communities in USA." International Journal of Tourism Sciences11 (161):186. 


\section{APPENDIX: SCATTERPLOTS OF TOURISM IN AFRICAN NATIONS}

Figure A-1: Scatterplot of Tourism and Poverty in African Nations

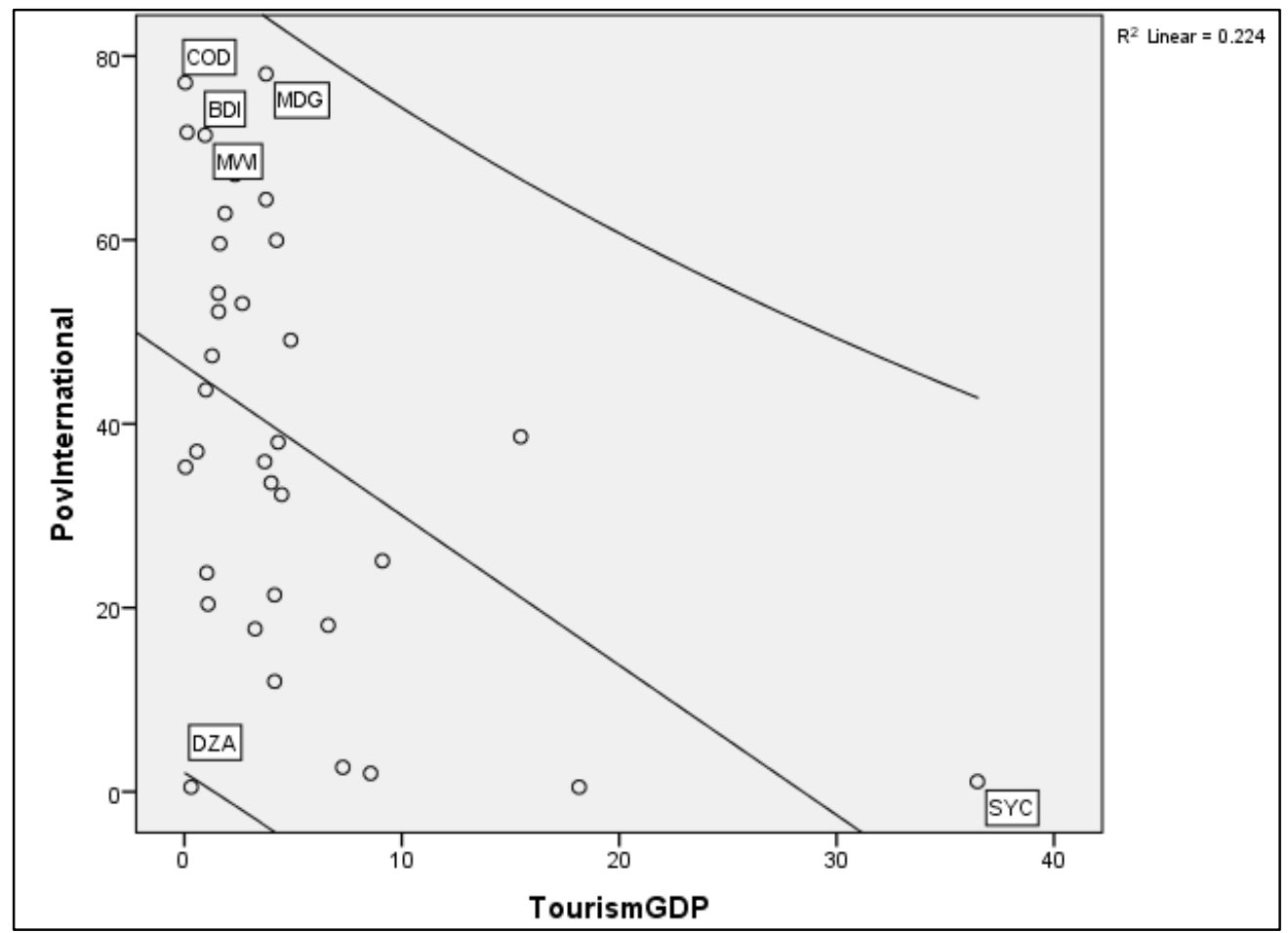


Figure A-2: Scatterplot of Tourism and Gini in African Nations

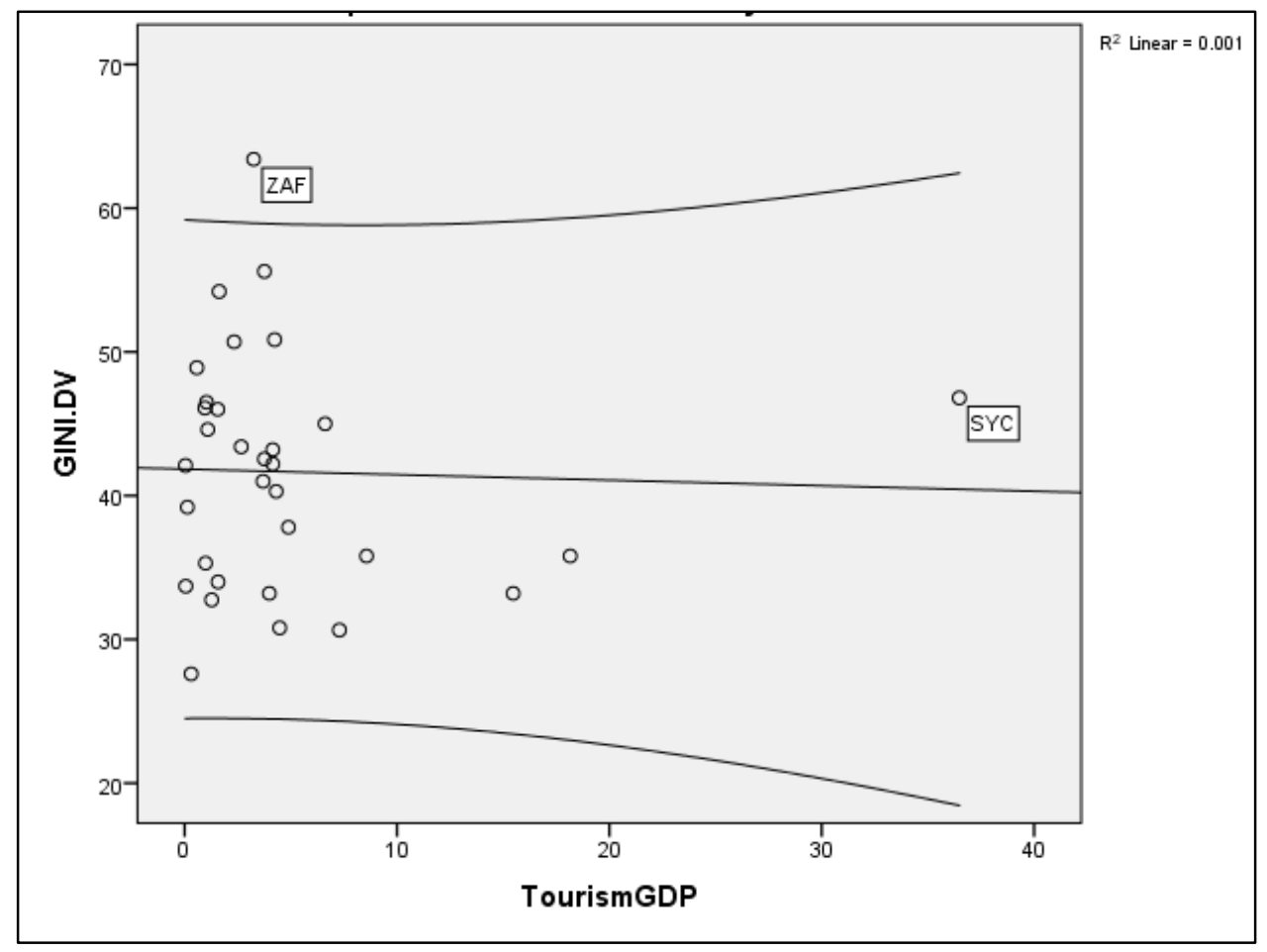

Figure A-3: Scatterplot of Tourism and Quality of Life in African Nations

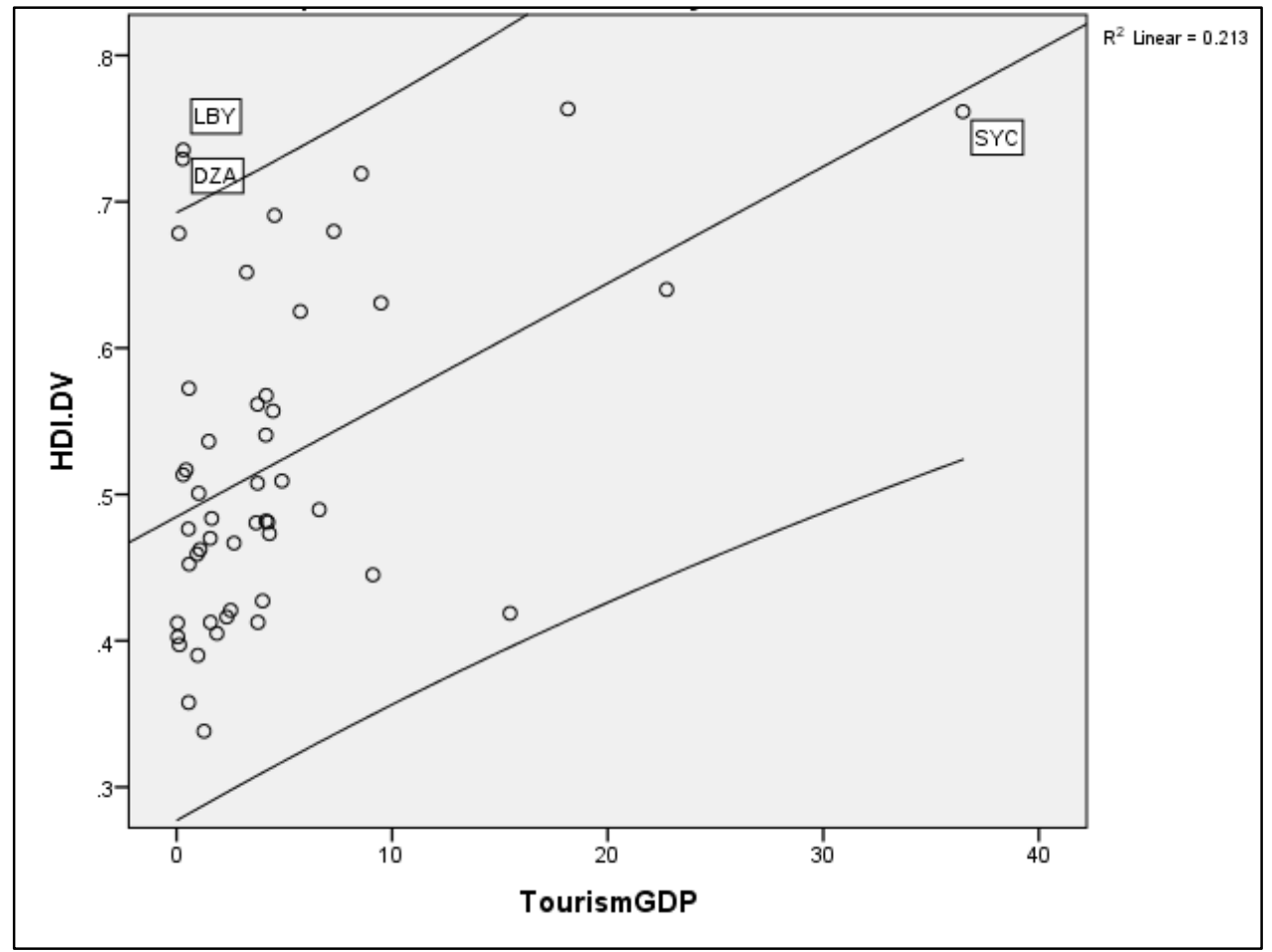

